\title{
Algeria: 2008 Article IV Consultation-Staff Report; Public Information Notice on the Executive Board Discussion; and Statement by the Executive Director for Algeria
}

Under Article IV of the IMF's Articles of Agreement, the IMF holds bilateral discussions with members, usually every year. In the context of the Article IV consultation with Algeria, the following documents have been released and are included in this package:

- $\quad$ The staff report for the 2008 Article IV consultation, prepared by a staff team of the IMF, following discussions that ended on November 15, 2008 with the officials of Algeria on economic developments and policies. Based on information available at the time of these discussions, the staff report was completed on December 23, 2008. The views expressed in the staff report are those of the staff team and do not necessarily reflect the views of the Executive Board of the IMF.

- $\quad$ A Public Information Notice (PIN) summarizing the views of the Executive Board as expressed during its January 21, 2009 discussion of the staff report that concluded the Article IV consultation.

- $\quad$ A statement by the Executive Director for Algeria.

The document listed below has been or will be separately released.

Statistical Appendix

The policy of publication of staff reports and other documents allows for the deletion of market-sensitive information.

\author{
Copies of this report are available to the public from \\ International Monetary Fund • Publication Services \\ $70019^{\text {th }}$ Street, N.W. • Washington, D.C. 20431 \\ Telephone: (202) 623-7430 • Telefax: (202) 623-7201 \\ E-mail: publications@imf.org Internet: http://www.imf.org
}

\section{International Monetary Fund Washington, D.C.}



INTERNATIONAL MONETARY FUND

ALGERIA

Staff Report for the 2008 Article IV Consultation

Prepared by the Staff Representatives for the 2008 Consultation with Algeria

Approved by Amor Tahari and David Marston

December 23, 2008

- The 2008 Article IV consultation discussions took place in Algiers during November 4-15, 2008. The staff team consisted of Messrs. Toujas-Bernaté (head), Loko, and Sensenbrenner, and Ms. Hijazi (all MCD).

- The mission met with Messrs. Djoudi (Minister of Finance) and Laksaci (Governor of the Bank of Algeria), other government officials, and representatives of the financial sector. Mr. Maherzi, Advisor to the Executive Director for Algeria, participated in the discussions. The mission issued a statement and held a press conference.

- Over recent years, the Fund and the authorities have focused, in the context of surveillance, on macroeconomic policies to sustain growth while safeguarding stability; and structural reforms aimed at promoting private sector activity. In addition, this year, discussions covered the impact of the global financial and economic crisis and the policy response.

- Algeria's exchange rate regime is a managed float with no preannounced path for the exchange rate. Algeria accepted the obligations of Article VIII, sections 2(a), 3, and 4, in 1997.

- Data provision to the Fund is broadly adequate for surveillance, despite shortcomings particularly in government finance statistics. 


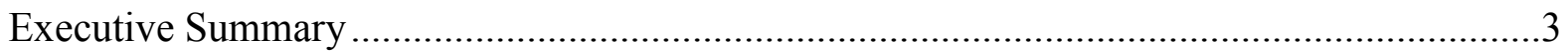

I. Background and Recent Developments.....................................................................4

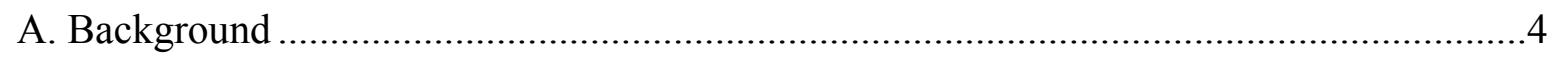

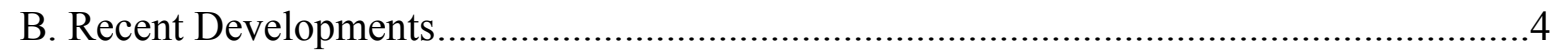

II. Global Financial Crisis, Outlook and Risks .............................................................

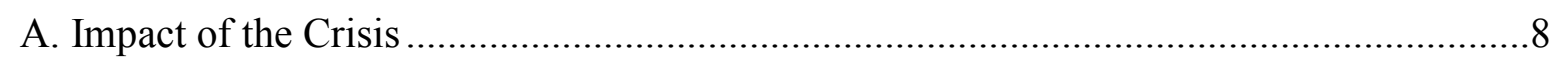

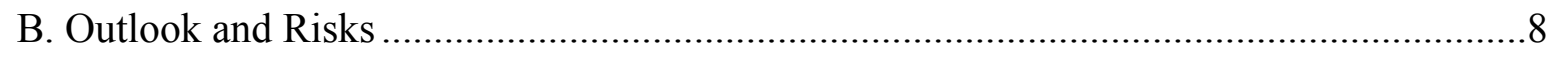

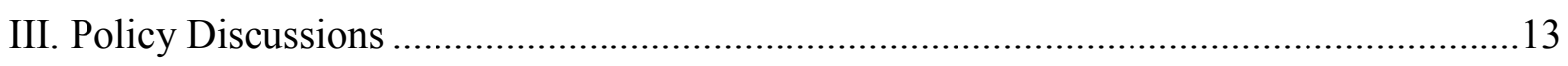

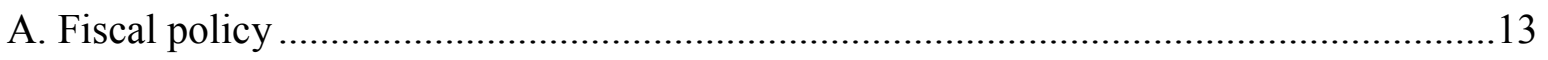

B. Monetary and Exchange Rate Policy ........................................................................ 15

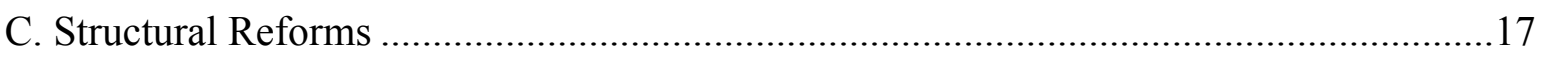

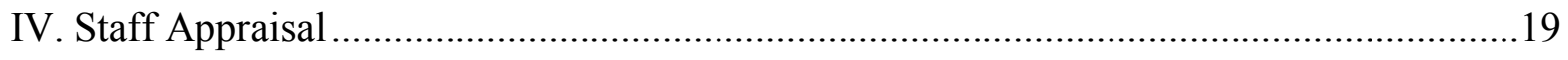

Boxes

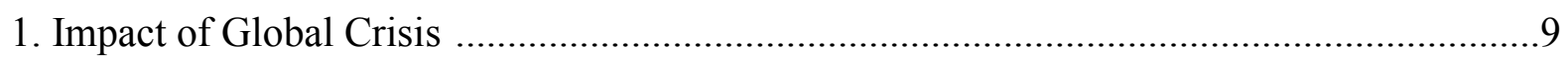

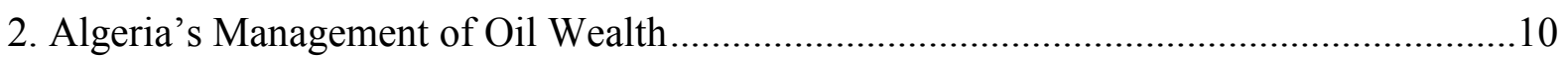

3. Exchange Rate Assessment and Competitiveness ....................................................... 16

\section{Figures}

Panel A. Algeria's Macroeconomic Situation is Stable, but the Economy

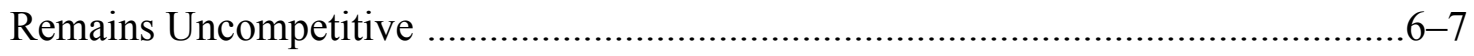

Panel B. Alternative Scenario Under Current Policies ......................................................12

Tables

1. Selected Economic and Financial Indicators, 2005-13 .............................................21

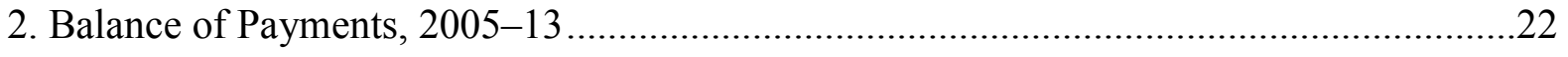

3. Summary of Central Government Operations, 2005-13 ................................................23

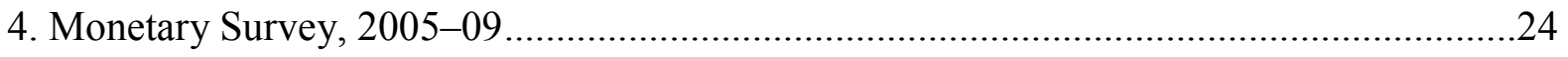

\section{Annexes}

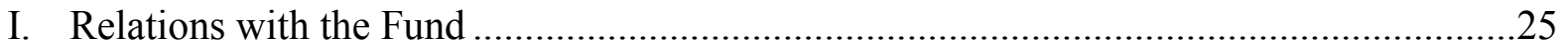

II. Relations with the World Bank ....................................................................................28

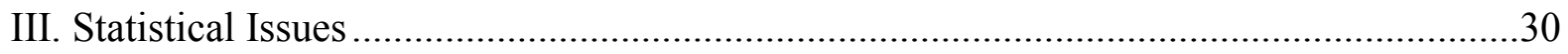




\title{
EXECUTIVE SUMMARY
}

Algeria has enjoyed several years of strong economic performance, with solid nonhydrocarbon growth, low inflation, and strong fiscal and external positions. External debt has been virtually eliminated, and the government has accumulated large savings in the oil stabilization fund (FRR). However, youth unemployment remains high, the economy is highly dependent on hydrocarbon exports, and productivity and business climate do not compare well with trading partners. The global financial crisis and declining oil prices highlight the pressing need to accelerate structural reforms to diversify the economy and facilitate sustained nonhydrocarbon growth.

\section{Key Issues and Policy Discussions}

\begin{abstract}
Algeria appears insulated from direct financial contagion, but lower oil prices will significantly weaken the external and fiscal positions. Pure financial channels of contagion are limited given the predominantly public financial sector, minimal external indebtedness, and prudent management of international reserves. The main risk of the crisis for Algeria is the projected significant decline in oil revenues, which, if prolonged, would eventually slow down the large public investment program and depress nonhydrocarbon growth.
\end{abstract}

The authorities intend to maintain the current fiscal stance to support domestic demand and nonhydrocarbon growth in the short term. Reserves in the FRR are sufficient to maintain the current fiscal stance in the short term. However, adjustments are warranted in the medium term to preserve fiscal sustainability, and the authorities would need to implement measures early on if risks of durably lower oil prices were to materialize.

The need for flexibility in monetary policy has become paramount given heightened uncertainty concerning the international outlook. Lower import prices should help keep inflation under control, potentially increasing the room for reducing interest rates, if necessary. Close coordination between monetary and fiscal policy would help sustain domestic demand in the face of the world economic slowdown.

Algeria's policies have been consistent with external stability. Staff estimates are consistent with the central bank's analysis that the real exchange rate of the dinar is close to its equilibrium level.

Diversifying the economy and sustaining nonhydrocarbon growth involve continued macroeconomic stability as well as better infrastructure, human capital, and public services. Structural reforms, which have been timid, are also needed-particularly to promote private sector development and improve financial intermediation, business climate, and further integration in the regional and world economies. 


\section{BACKGROUND AND RECENT DEVELOPMENTS}

\section{A. Background}

1. The political situation remains stable, but periodic bomb attacks underline the threat posed by Al-Qaeda in the Maghreb. Presidential elections will take place in 2009, and President Bouteflika will likely run for a third term.

2. Algeria has enjoyed several years of strong economic performance, but the economy remains highly dependent on hydrocarbon exports. Average annual GDP growth in the nonhydrocarbon sector (NHGDP) - around 55 percent of total GDP - reached about 6 percent and inflation about 4 percent on average in 2003-07. Total GDP growth averaged $4 \frac{1}{2}$ percent, as oil production was less buoyant in 2006-07. High export prices for oil and natural gas have strengthened the fiscal and external positions, external debt has been virtually eliminated, and the government has accumulated large savings in the oil stabilization fund (FRR). ${ }^{1}$ However, youth unemployment remains high, and productivity and business climate compare poorly with trading partners (Panel A). Moreover, the economy and the budget are highly dependent on hydrocarbons, which represent 98 percent of total exports and 75-80 percent of budget revenues.

3. The immediate challenge is to adopt adequate policies in response to the global crisis. Algeria appears insulated from direct financial contagion, but continued low oil prices and the slowdown of global energy demand would dramatically weaken the fiscal and external positions. This could constrain economic growth in the medium term, should FRR reserves prove insufficient to maintain the pace of the massive Public Investment Program (PIP).

4. The crisis highlights the pressing need to accelerate structural reforms to diversify the economy, facilitate sustained nonhydrocarbon growth, and further lower unemployment. Key structural reforms in the areas of Fund's surveillance include financial sector reforms, tax reform, and further integration in the regional and global economies.

\section{B. Recent Developments}

\section{Economic growth continues to be strong and inflation subdued.}

- $\quad$ NHGDP growth reached 6.3 percent in 2007, driven by the PIP. Early indications suggest a slightly lower outcome in 2008, reflecting a poor cereal harvest. Overall growth is projected at about 3 percent, as sluggish demand in Algeria's export markets is depressing hydrocarbon output.

\footnotetext{
${ }^{1}$ Given that external and domestic public debts are very low and unlikely to rise significantly under plausible scenarios, this report does not include a debt sustainability analysis.
} 
- High world oil prices until mid-2008 have further strengthened the external position, with a current account surplus above 20 percent of GDP in 2007-08 and official reserves reaching \$136 billion at end-October 2008 (2 1/2 years of imports), despite the ongoing surge in PIP-related imports.

- Inflation remains among the lowest in the region, reflecting stable domestic energy prices, high import content of domestic demand, subsidies on wheat and milk, and prudent monetary policy. Average annual CPI inflation was 4.2 percent at end-October 2008 (1.2 percent, when excluding food).

- The nominal and real effective exchange rates depreciated slightly on average by 0.1 percent and 1.2 percent, respectively, during January-September 2008. Both exchange rates have been volatile on a monthly basis, reflecting mostly dollar/euro volatility.

- $\quad$ The overall fiscal position remains strong despite the continued fiscal

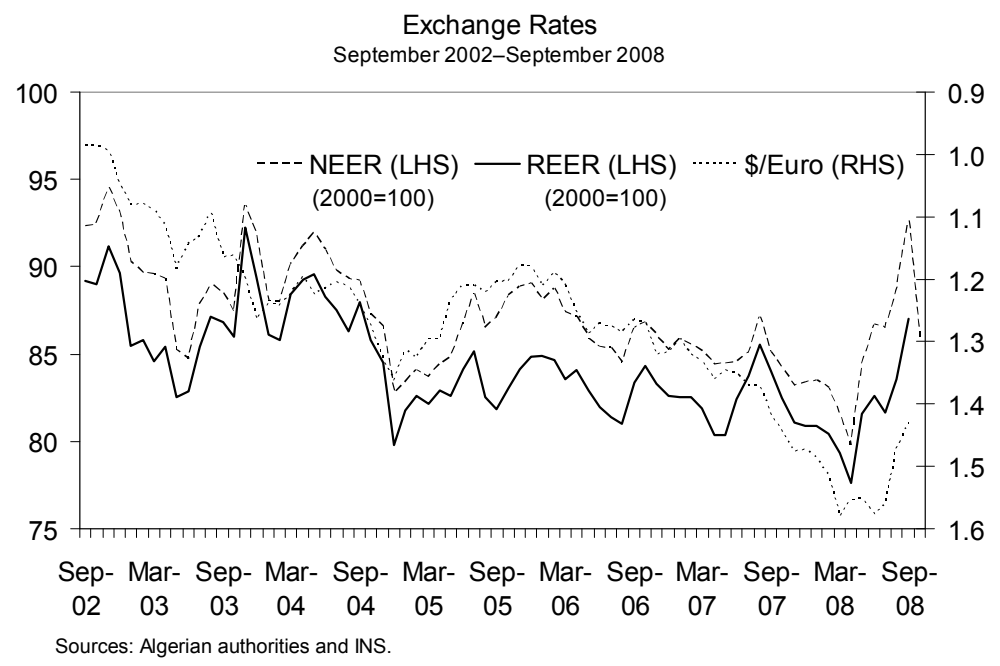
expansion. The 2008 supplementary budget increased PIP outlays, the wage bill, ${ }^{2}$ and transfers to social sectors, including milk and wheat subsidies. As a result, the nonhydrocarbon primary deficit will exceed 52 percent of NHGDP, compared with 44 percent in 2007 . However, higher hydrocarbon revenue will more than offset the increase in expenditures, almost doubling the overall budget surplus to 8 percent of GDP.

\footnotetext{
${ }^{2}$ This increase is due to a broad-based reform of the civil service launched in 2007, including the establishment of a new pay and grading system, to improve efficiency in the delivery of public goods, retain skilled staff, and boost hiring in the security services.
} 
Panel A. Algeria's Macroeconomic Situation is Stable ...

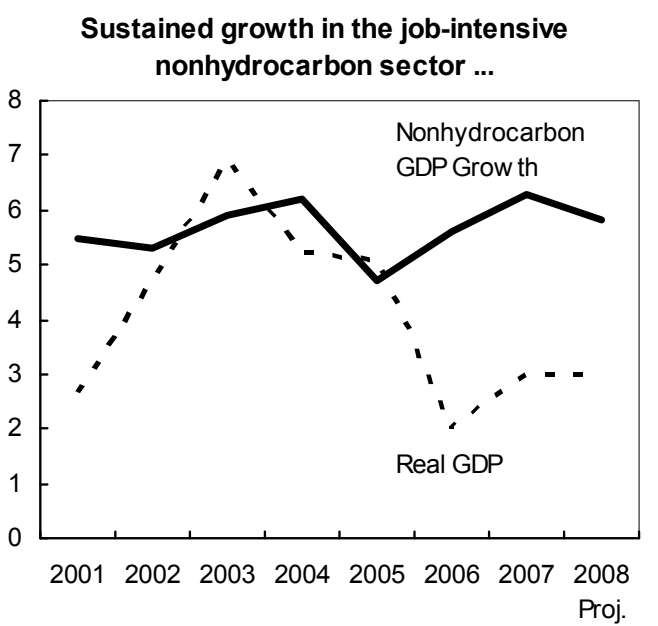

... has reduced unemployment, although it remains high among the youth.

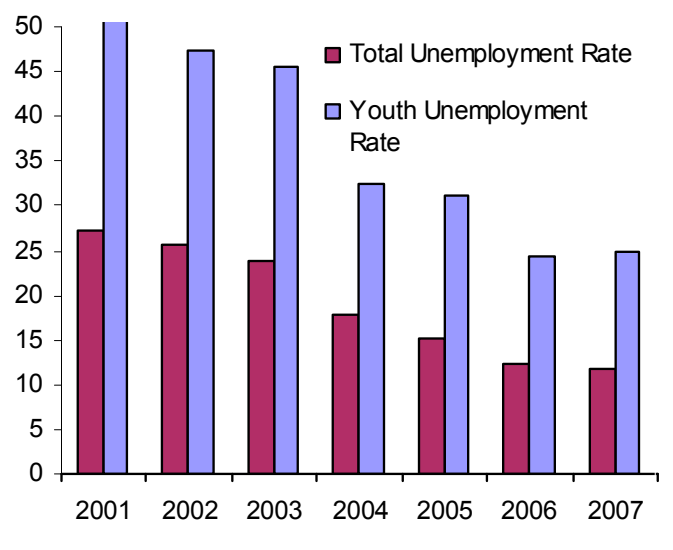

Low inflation...
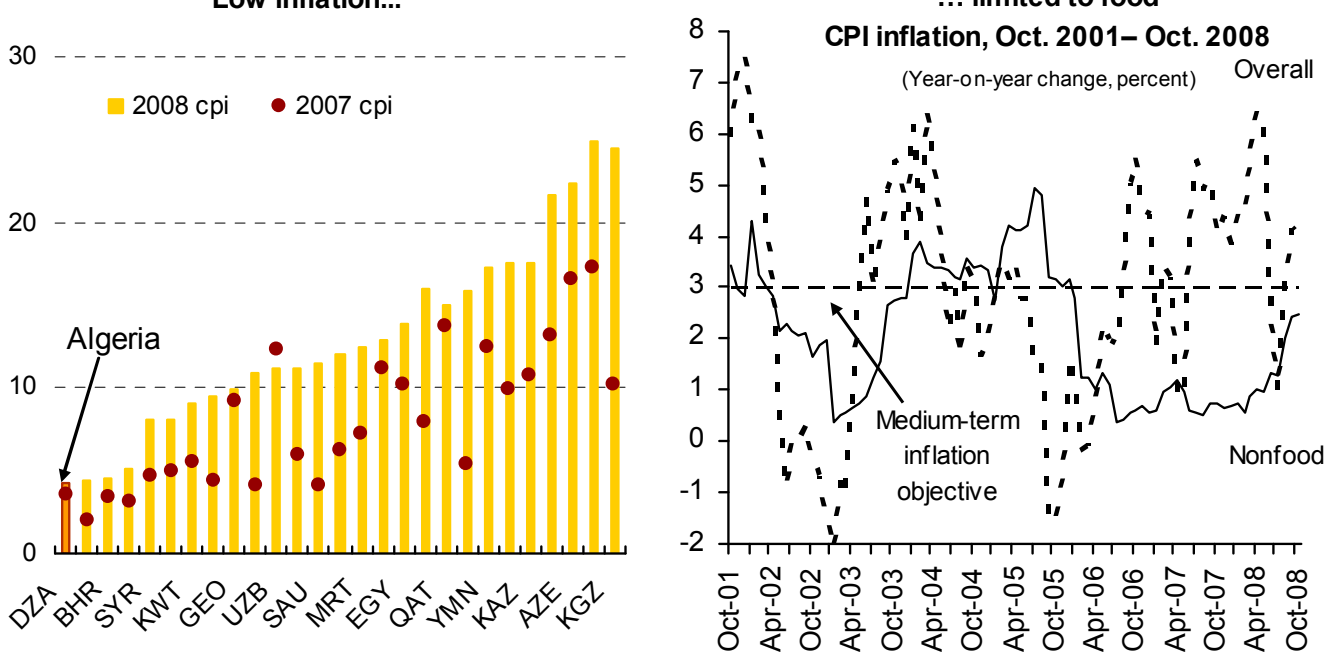

\section{Soaring receipts from hydrocarbon exports have boosted both the external position ...}

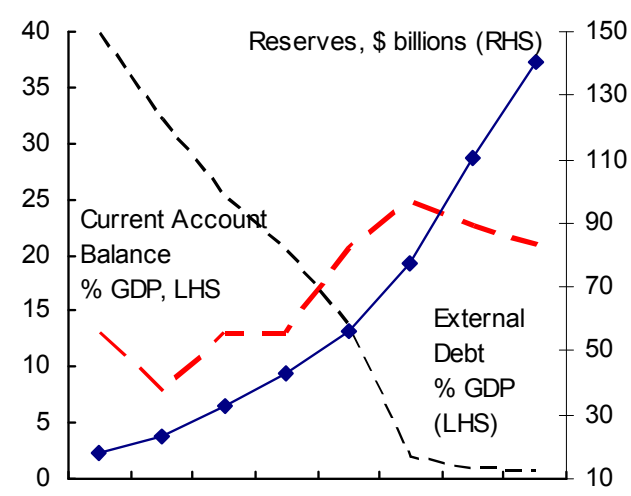

... and the fiscal position, despite a large public investment program in infrastructure and human capital.

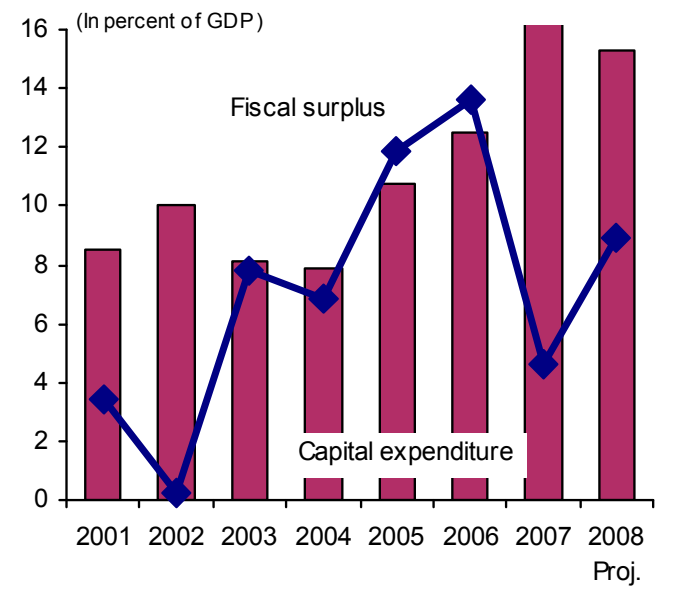

Sources: Algerian authorities; and Fund staff estimates and projections. 


\section{... But The Economy Remains Uncompetitive}

Undiversified Exports
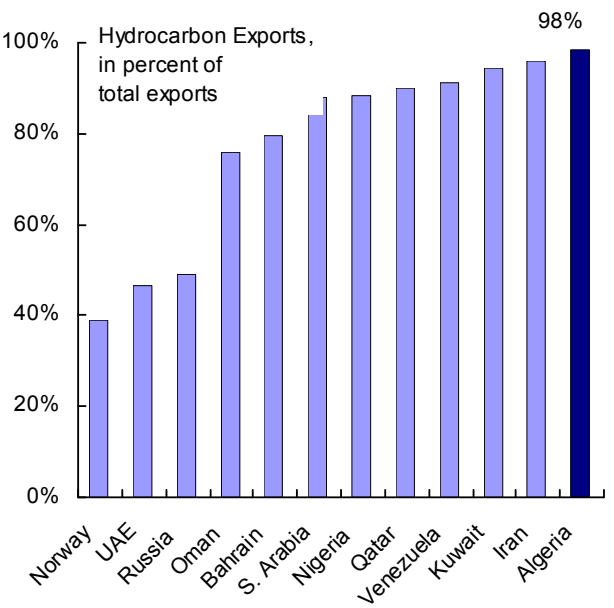

Widening Productivity Gap

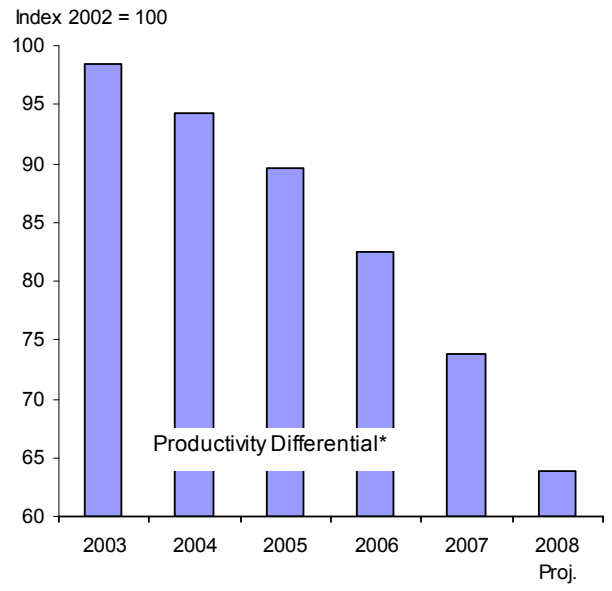

Sluggish FDIs

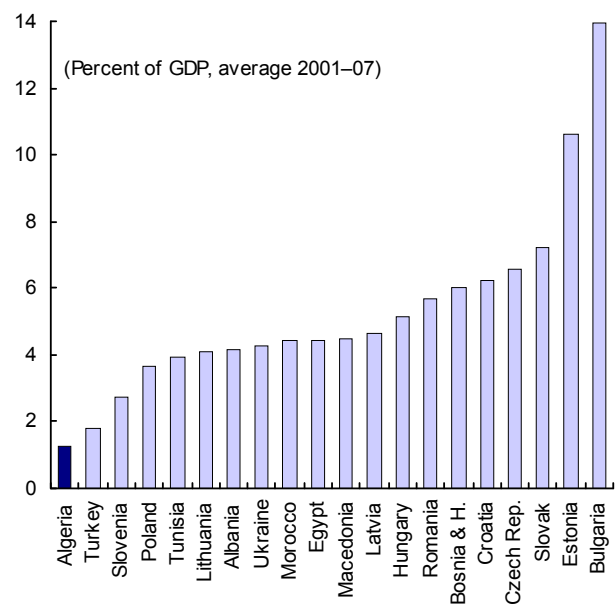

Low Competitiveness WEF competitiveness index

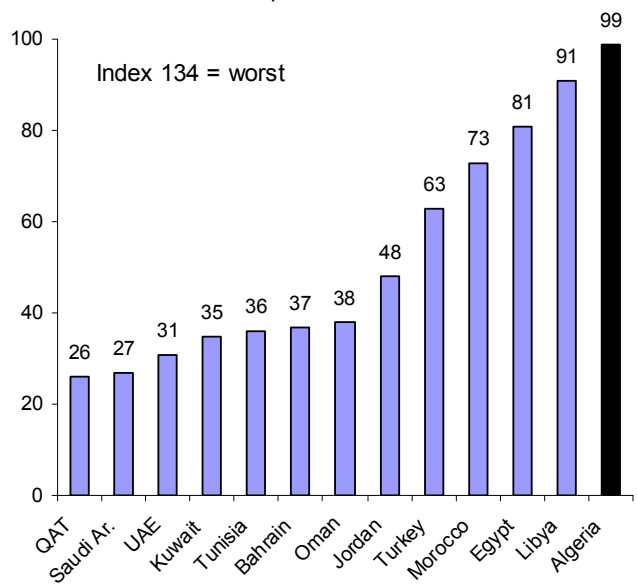

${ }^{*}$ Ratio of Algeria labor productivity over its trading partners.
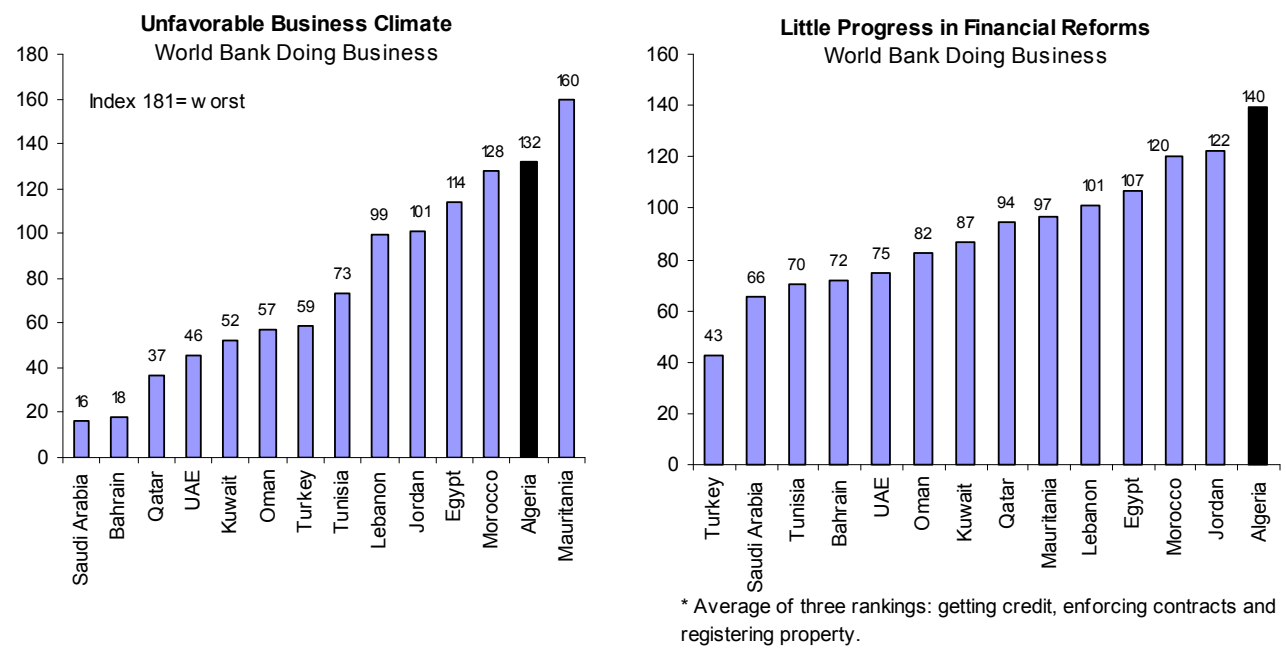

Sources: Algerian authorities; and Fund staff estimates and projections; World Bank Doing Business; and World Economic Forum (WEF). 


\section{Global Financial Crisis, OUtlook, AND Risks}

\section{A. Impact of the Crisis}

6. Pure financial channels of contagion are limited (Box 1). Policy choices over the past few years have effectively insulated the economy and financial system from global financial turmoil. The authorities eschewed external borrowing and used instead the ample domestic liquidity to finance the economy's large investments. Public ownership of the largest banks makes a credit crunch unlikely. The country's foreign exchange assets and management of associated risks are concentrated at the central bank, through the surrender of hydrocarbon export proceeds and the requirement for banks to deposit end-of-day foreign exchange balances at the central bank.

\section{Economic channels of contagion from lower oil prices and the recession in} Europe to domestic demand and output could become significant. Domestic demand depends overwhelmingly on investment spending by the government and Sonatrach. Both have accumulated significant savings ( $\$ 60$ billion and $\$ 17$ billion, respectively), which would help cushion the impact of lower hydrocarbon revenues on their investments (Box 2).

\section{A global recession, especially in Europe, could depress Algeria's exports of oil} and natural gas (NG). Liquid petroleum exports (crude oil, refined products) could be less affected than NG exports, because they are diversified worldwide. However, Algeria's NG exports are mainly to Europe (Italy, Spain, France, and United Kingdom), and cannot be easily diverted elsewhere. Therefore, a more pronounced recession in Europe could further depress NG exports.

\section{B. Outlook and Risks}

\section{Lower oil prices will significantly affect the external current account and overall} fiscal position, but the short-term outlook remains encouraging. The significant projected decline in WEO oil prices (from $\$ 98 /$ bbl in 2008 to $\$ 54 /$ bbl in 2009), and high imports induced by PIP and Sonatrach investments, would shift the current account to a deficit of 3 percent in 2009, but the reserve cover would remain above two years of imports. The overall fiscal balance would turn negative for the first time since 1999, with a deficit of $11 \frac{1 / 2}{2}$ percent of GDP in 2009. ${ }^{3}$ NHGDP growth is projected at about 6 percent in 2009 provided the government and Sonatrach draw down their savings to continue their substantial investment programs. Reflecting a recession in Europe, staff projects lower hydrocarbon exports so that overall growth would decelerate to $2 \frac{1}{2}$ percent. Inflation would stay low.

\footnotetext{
${ }^{3}$ The 2009 budget envisages a slight drop in the nonhydrocarbon primary deficit to $511 \frac{1}{2}$ percent of NHGDP.
} 


\section{Box 1. Impact of Global Crisis}

1. Direct financial channels of contagion are limited, reflecting long-standing factors dampening Algeria's integration in the global financial system.

- Total external debt is minimal, at 3 percent of GDP in 2008. In particular, thanks to high hydrocarbon export revenues, the ratio of external public debt to GDP was cut to less than 1 percent of GDP.

- The banks' external liabilities are small, at less than 1 percent of total liabilities. The banks are required to deposit their end-of-day foreign exchange balances at the central bank, thereby transferring the risk associated with claims on foreign correspondent banks.

- The banking system is 90 percent public, the rest being foreign-owned, mostly by prominent international banks. Should one such bank withdraw, its small size would make it easy for a public bank to step in with the backing of the government. As long as nonhydrocarbon growth is sustained, credit risk on bank loans would be contained.

- Foreign portfolio investment is not yet authorized.

- FDI has been small so far, on average 1 percent of GDP per year for a total of $\$ 8.5$ billion in the past ten years. Profit repatriation, which may have increased with the crisis, amounted to a drain of less than 1 percent of international reserves.

2. A recession in the world, and particularly in Europe, would lower the volume of hydrocarbon exports.

3. Lower oil prices over an extended period could depress NHGDP growth in the medium term.

- Nonhydrocarbon growth is almost entirely driven by large investment programs. $\mathrm{NH}$ exports represent about 2 percent of NHGDP. A scaling back or delay in planned investments could affect growth significantly.

- Sonatrach has cash reserves, covering about half of its planned investments. Its new joint venture projects in petrochemicals have been structured to rely exclusively on local financing, with the exception of the minority equity stakes of the foreign partners. However, much lower hydrocarbon prices and a world Algeria: Exports, Remittances, and FDI, 2007 (\$ millions)

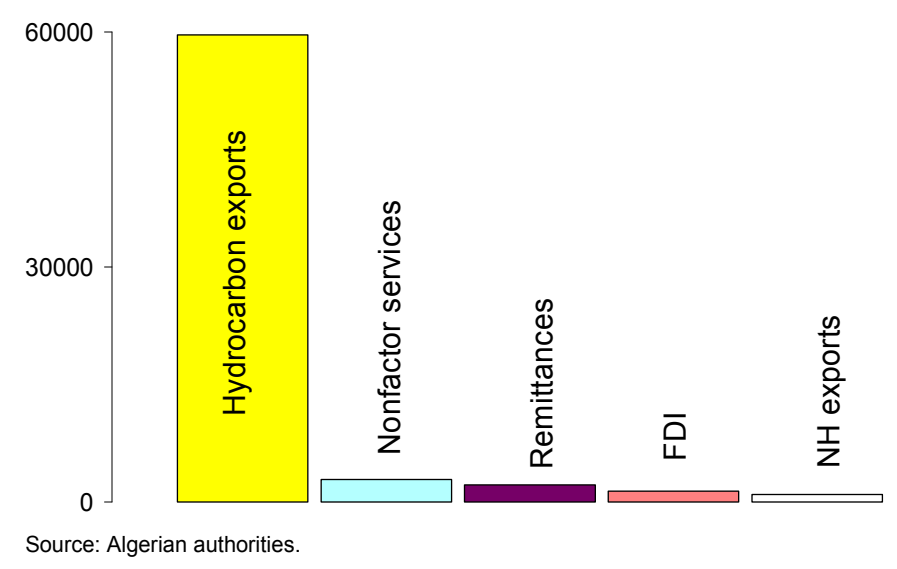
recession would delay some projects.

4. Other potential channels are limited (e.g., tourism, remittances) (see chart). 


\section{Box 2. Algeria's Management of Oil Wealth}

Algeria's hydrocarbon receipts are split between the government and Sonatrach. Around two thirds accrue to the budget.

The financial wealth accumulated from hydrocarbon exports has been managed prudently, obeying two main principles: centralization of risk management at the central bank; and investment in foreign assets typical of central banks. Hydrocarbon export receipts are fully surrendered to the central bank and are part of international reserves. These reserves have been split since 2004 between a small "liquid" part and a large portfolio of high-grade fixed-income securities. A central bank unit is the exclusive manager, implementing the

Algeria: Government Financial Assets and Liabilities,

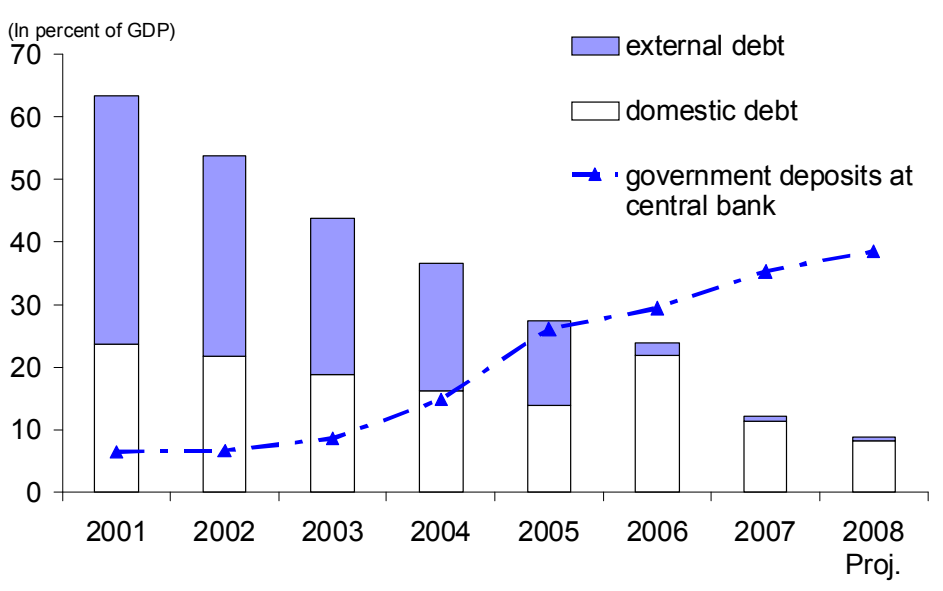
currency and duration benchmarks that the authorities establish yearly. Active reserve management has returned between 3 percent and 4 percent per year since $2004 .{ }^{1}$ Returns on reserves are ultimately transferred to the budget in the form of central bank dividends.

Algeria's FRR is merely a subaccount of the government at the central bank in dinars. It therefore lacks governance arrangements and investment goals of sovereign wealth funds used by other large commodity exporters. The authorities continue to view the FRR as temporary and emphasize the need for utmost prudence in investing financial wealth. Arrangements for the custody of Sonatrach's financial wealth are broadly similar. It is deposited in local currency in the public bank that has been its long-standing anchor bank. To meet Sonatrach's liquidity requirements, the bank mostly holds short-term claims on the central bank, via deposit auctions and the marginal deposit facility. This set-up allows the authorities to separate the management of financial risk, centralized at the central bank, from the management of the country's oil and gas businesses by Sonatrach.

${ }^{1}$ For comparison, Norway's SWF earned an average annual return of 5 percent (since 1997), on a riskier portfolio and before fees (BIS Quarterly Review, June 2008). 
10. The medium-term outlook would remain relatively favorable under the staff's baseline. With oil prices gradually recovering to $\$ 78 / \mathrm{bbl}$ in 2013 , current policies appear sustainable. The fiscal stance could be maintained as FRR reserves (37 percent of 2008 GDP) would cover the deficits over 2009-13. Under this assumption, average annual NHGDP growth is projected at about $51 / 2$ percent, and inflation would stay below 4 percent. The current account balance would be only slightly negative, and official reserves would stay close to two years of import cover. The overall fiscal deficit would be reduced, along with the projected increase in oil prices, to about 5 percent of GDP by 2013.

Algeria: Medium-Term Baseline Projections, 2007-13

\begin{tabular}{|c|c|c|c|c|c|c|c|}
\hline & 2007 & 2008 & 2009 & 2010 & 2011 & 2012 & 2013 \\
\hline Real GDP growth & 3.0 & 3.0 & 2.6 & 3.9 & 3.9 & 4.1 & 4.4 \\
\hline Hydrocarbon sector & -0.9 & -0.6 & -1.0 & 0.0 & 0.7 & 1.5 & 2.3 \\
\hline Nonhydrocarbon sector & 6.3 & 5.8 & 6.0 & 5.8 & 5.6 & 5.5 & 5.5 \\
\hline CPI inflation (period average) & 3.6 & 3.9 & 3.8 & 3.4 & 3.3 & 3.2 & 3.1 \\
\hline Current account balance (in percent of GDP) & 22.6 & 20.2 & -2.9 & -0.9 & -1.0 & -1.3 & -1.5 \\
\hline Nonhydrocarbon primary balance (in percent of NHGDP) & -44.0 & -52.1 & -51.4 & -49.7 & -47.9 & -44.7 & -42.5 \\
\hline Overall fiscal balance (in percent of GDP) & 4.5 & 8.2 & -11.5 & -8.6 & -7.3 & -5.9 & -5.2 \\
\hline Oil prices $(U S \$ / b b l)$ & 71.1 & 97.5 & 54.3 & 64.8 & 71.3 & 75.0 & 77.5 \\
\hline
\end{tabular}

Sources: Algerian Authorities; and Fund staff estimates and projections.

11. Risks to the outlook are essentially related to the recession in Europe and the significant decline in oil revenues, which, if prolonged, would depress growth.

Hydrocarbon output could record a more pronounced slowdown if the recession in Europe were to be deeper and longer than currently projected. Moreover, nonhydrocarbon growth would be lower if oil prices stay low for an extended period. In a scenario with oil prices at $\$ 40 /$ bbl until 2013, current policies could not be maintained very long because the overall fiscal deficit would deplete FRR reserves by 2011 (Panel B). The required fiscal adjustment would include paring back of the PIP, implying slower nonhydrocarbon growth and likely higher unemployment.

12. The outlook also rests on decisive actions to promote private sector development and economic diversification. NHGDP growth would be lower in the absence of substantial improvements in productivity and business climate. The PIP and structural reforms aim to elicit the hoped for private sector supply response. 
Panel B. Alternative Scenarios Under Current Policies
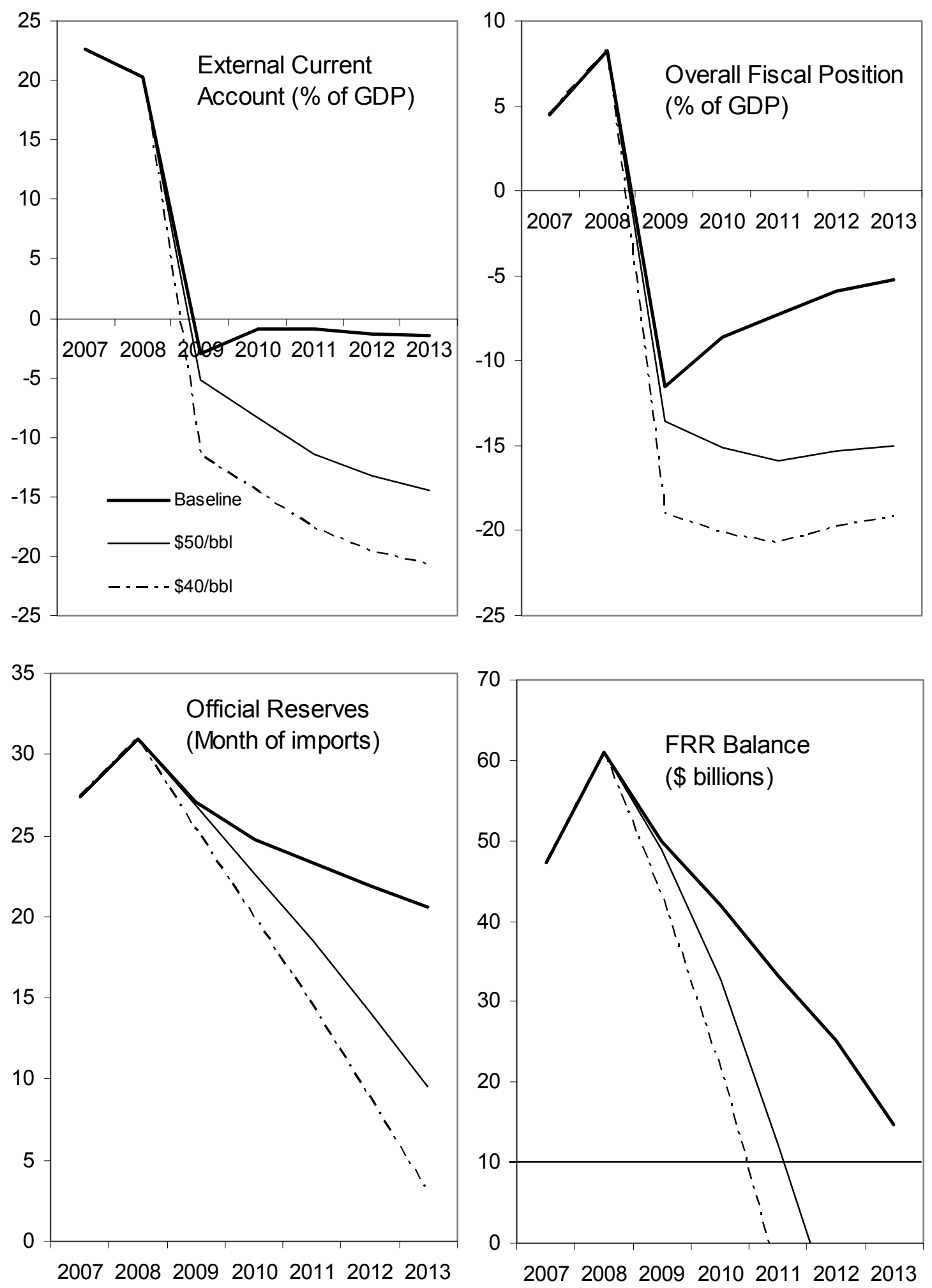

Sources: Algerian authorities; and Fund staff estimates and projections. 


\section{Policy Discussions}

13. Discussions focused on policies to support growth, and ensure external stability in an environment of global financial crisis and declining oil prices.

\section{A. Fiscal Policy}

\section{Background and Staff Analysis}

\section{Gradual fiscal adjustment is warranted in the medium term to preserve fiscal} sustainability. The recent steep increase in current expenditure, driven by the wage bill, PIP-related recurrent costs, and current transfers, ${ }^{4}$ has pushed the nonhydrocarbon fiscal deficit above its long-term sustainable level. The expected decline in the PIP by 2013 will lower the nonhydrocarbon deficit to 43 percent of NHGDP, still above the sustainable level. This deficit would need to be reduced to 34 percent of NHGDP in the medium term to ensure intergenerational equity. ${ }^{5}$ Adjustment measures, to achieve this objective, could include better control of current expenditure, prioritization of investment projects, and enhanced nonhydrocarbon tax collection. ${ }^{6}$ The adjustment would need to be implemented more rapidly and forcefully if the risk of durably lower oil prices materializes. Specifically:

- Rationalizing current expenditure. The authorities' broad-based civil service reform has boosted the wage bill. This can pose risks for competitiveness, if it is extended to the rest of the economy, and fiscal sustainability. The wage bills should therefore be contained. There is also scope for improved targeting of transfers and subsidies.

- Prioritizing capital expenditures. The PIP appropriately aims at building and improving public infrastructure, and developing human capital. But projects could be prioritized and phased.

- Improving nonhydrocarbon tax collection. There is a need to continue reforms aimed at strengthening the efficiency of the tax and customs administration. Specifically, measures should focus on eliminating exemptions, lowering personal tax rates, and simplifying customs formalities.

\footnotetext{
${ }^{4}$ For instance, the 2009 budget includes about 0.7 percent of NHGDP to provide aid and support for students from poor families or those living in remote areas. The number of beneficiaries increased to 2.6 million students from 500,000 in 1999. Moreover, the government provides free lunch for 70 percent of primary school pupils.

${ }^{5}$ Staff uses a permanent income framework (PIF), based on a constant wealth per capita criterion, to assess sustainability.

${ }^{6}$ By 2013, with measures, current and capital expenditures could be $5 \frac{1 / 2}{2}$ percent and 2 percent of NHGDP lower, respectively. The revenue-to-NHGDP ratio could be enhanced by 1 percent of NHGDP.
} 
15. The fiscal policy stance will deviate from the sustainable path in the short term in order to support NH growth and mitigate the impact of the global economic downturn. The 2009 nonhydrocarbon fiscal deficit reflects the authorities plan to continue: (a) carrying out the much needed capital expenditures, including infrastructures; and (b) completing the broad based civil service reform, including the establishment of a new pay and grading system, to improve the quality of public goods and retain skilled managers. FRR reserves are sufficient to maintain this fiscal stance aimed at sustaining domestic demand and protecting nonhydrocarbon GDP growth and employment. The authorities could also increase slightly domestic public debt, which stands at 6 percent of GDP, to finance part of the PIP and revitalize the domestic debt market.

Algeria: Nonhydrocarbon Primary Deficit, 2009-13 (In Percent of NHGDP)

\begin{tabular}{lrrrrr}
\hline & 2009 & 2010 & 2011 & 2012 & 2013 \\
\hline Sustainable primary deficit & -40.0 & -38.4 & -36.9 & -35.5 & -34.2 \\
Staff projections for actual primary deficit & -51.4 & -49.7 & -47.9 & -44.7 & -42.5 \\
Crude oil export unit value (US\$/bbl) & 54.3 & 64.8 & 71.3 & 75.0 & 77.5 \\
\hline
\end{tabular}

Sources: Algerian authorities; and Fund staff estimates and projections.

16. Scrutiny over expenditure quality and efficiency should be intensified. To that end, it is important to continue implementing the recommendations of the Public Expenditure Review (PER) conducted in cooperation with the World Bank in 2005-06, ${ }^{7}$ accelerate budget modernization, and further strengthen fiscal governance by implementing the recommendations of the 2004 fiscal ROSC. ${ }^{8}$

\section{Authorities' Views and Policy Intentions}

17. For the time being, the authorities intend to maintain the fiscal stance of the 2009 budget. They expect to limit the impact of the global crisis on the economy by drawing down FRR reserves. They remain convinced that continued implementation of the PIP will help promote private investment, sustain nonhydrocarbon growth, and reduce unemployment.

\footnotetext{
${ }^{7}$ Main recommendations were to select projects more closely with sector strategies in the context of a mediumterm expenditure framework, and modernize management and control systems for public investment and the budget.

${ }^{8}$ Main recommendations were to: ensure compliance with the legal framework; reduce quasi-fiscal activities; expand and clarify the fiscal information submitted to parliament; extend the publication of fiscal data; address outstanding deficiencies in data and fiscal reporting; and publish external audit reports.
} 
18. The authorities are developing contingency plans to reduce public spending in the medium term if oil prices remain low. They are aware of the need for policy adjustments if oil prices stay low for an extended period, and underscored the scope for reducing current expenditure and postponing some PIP spending.

19. The authorities remain committed to long-term fiscal sustainability. They indicated that the fiscal deficit will likely be lower than budgeted in 2009, as wheat and milk subsidies (3.2 percent of NHGDP) will decline with lower international prices. They noted that the envisaged increase in the wage bill (15 percent) reflects mostly the final step of the implementation of civil service reform and agreed on the importance of containing wages to ensure fiscal sustainability and competitiveness.

20. The authorities are continuing reforms to strengthen the efficiency of the tax and customs administration, and further increase nonhydrocarbon revenue. Specifically, the corporate tax was reduced from 25 percent to 19 percent, a unit was established to monitor tax expenditures, and IT modernization of the tax and customs administration continues with e-filing. These measures are in line with FAD's technical assistance recommendations on tax policy (2007) and tax expenditure (2008).

21. The authorities want to ensure the quality and efficiency of public expenditure. In line with PER recommendations, the National Agency of Investment for Development has finalized the guidebooks on selection of major investment projects in line with sectoral priorities and implementation, and monitoring and evaluation of projects. Progress is being made to modernize budget management and strengthen fiscal governance, including with the submission of the draft organic budget law to parliament.

\section{B. Monetary and exchange rate policy}

\section{Background and Staff Analysis}

22. The need for flexibility in monetary policy has become paramount given the uncertain international outlook. Although public spending, Sonatrach investments, and further prepayment of government securities have increased banking system liquidity, BA has been able to limit its impact on inflation, including by using well-defined liquidity absorption facilities and flexible exchange rate management. Lower import prices should help keep inflation under control, potentially increasing the room for reducing interest rates. In this regard, the desired cost of credit in the economy could be signaled more clearly by including BA's refinancing rate in further cuts in policy rates. In any event, the global crisis demands close coordination between monetary and fiscal policy to sustain domestic demand.

23. Algeria's exchange rate policy remains consistent with external stability. An update of the 2007 Article IV exchange rate assessment indicates that the real effective exchange rate remains close to its equilibrium level (Box 3). Both have been broadly stable. There is, however, room to dampen month-to-month NEER volatility by distributing the 
volatility of the dollar/euro exchange rate - its main determinant - more evenly between the dinar/dollar and dinar/euro rates.

\section{Authorities' Views and Policy Intentions}

24. The authorities have strengthened coordination between monetary and fiscal policies. The minister of finance praised the collaboration with BA and noted that BA's cut in its deposit rates had reflected agreement to deepen it. The intensification of the global crisis prompted treasury and BA to formalize a crisis working group, and the authorities expressed interest in its more frequent interaction with staff. They were also receptive to the suggestion of including BA's refinancing rate in further potential policy moves.

25. BA will continue its policy of flexible exchange rate management to support its monetary policy objective. BA noted that this policy has maintained the REER close to its equilibrium level. At the same time, the authorities agreed with staff that the assessment of the equilibrium exchange rate should be treated with great caution in the case of Algeria because of the oil price uncertainty.

\section{Structural Reforms}

\section{Background and Staff Analysis}

26. The global crisis highlights the importance of economic diversification. The development of NH exports would mitigate Algeria's hydrocarbon risk that the crisis is bringing to the fore. However, sustained growth and job creation in the $\mathrm{NH}$ economy require major gains in productivity. This involves continued macroeconomic stability as well as better infrastructure, human capital, and public services - all goals of the PIP. But structural reforms, which have been timid, will also be key_-particularly for improving financial intermediation, business climate, and integration in the regional and world economies.

\section{More effective financial intermediation would help channel Algeria's large} saving into private sector investment, which remains low outside the oil sector. The banking system does not pose macroeconomic risk: it is adequately capitalized and profitable, has satisfactory provisioning practice, and does not rely on foreign nor on market funding. While the overall classified loan-ratio remained stable, loans requiring 100 percent provisioning rose to 22 percent in 2007, reflecting supervisory progress in identifying private conglomerates. The capital adequacy ratio could increase somewhat with the roll-out of the 


\section{Box 3. Exchange Rate Assessment and Competitiveness}

The updated assessment ${ }^{1}$ suggests that the exchange rate remains broadly in line with fundamentals. The assessment uses CGER's equilibrium real effective exchange rate (EREER) and macroeconomic balance (MB) approaches. The EREER suggests a small undervaluation, while the MB suggests a small overvaluation. However, these results are very sensitive to assumptions on future international oil prices as shown below.

\section{Exchange Rate Misalignment}

(In percent)

\begin{tabular}{lccr}
\hline & EREER approach & MB approach & Average \\
\hline 2007 Article IV & 6.9 & 0.0 & 3.5 \\
Update: & & & -0.6 \\
Baseline scenario (WEO oil price) & 3.6 & -4.8 & -10.4 \\
Middle scenario (oil price at \$50) & -5.7 & -15.1 & -15.3 \\
Low scenario (oil price at \$40) & -9.3 & -21.3 &
\end{tabular}

Other competitiveness indicators show no evidence of undervaluation. NH exports remain very low. World Economic Forum ranked Algeria $99^{\text {th }}$ out of 134 countries, and behind key regional competitors. Algeria's competitive advantage is macroeconomic stability (ranked $5^{\text {th }}$ in the world). The main weaknesses are related to the lack of infrastructures, innovation and sophistication factors. Areas of particular concern are the perceived poor functioning of goods, labor and financial markets.

Algeria Competitiveness: Strengths and Weaknesses

(Ranking out of 134 countries)

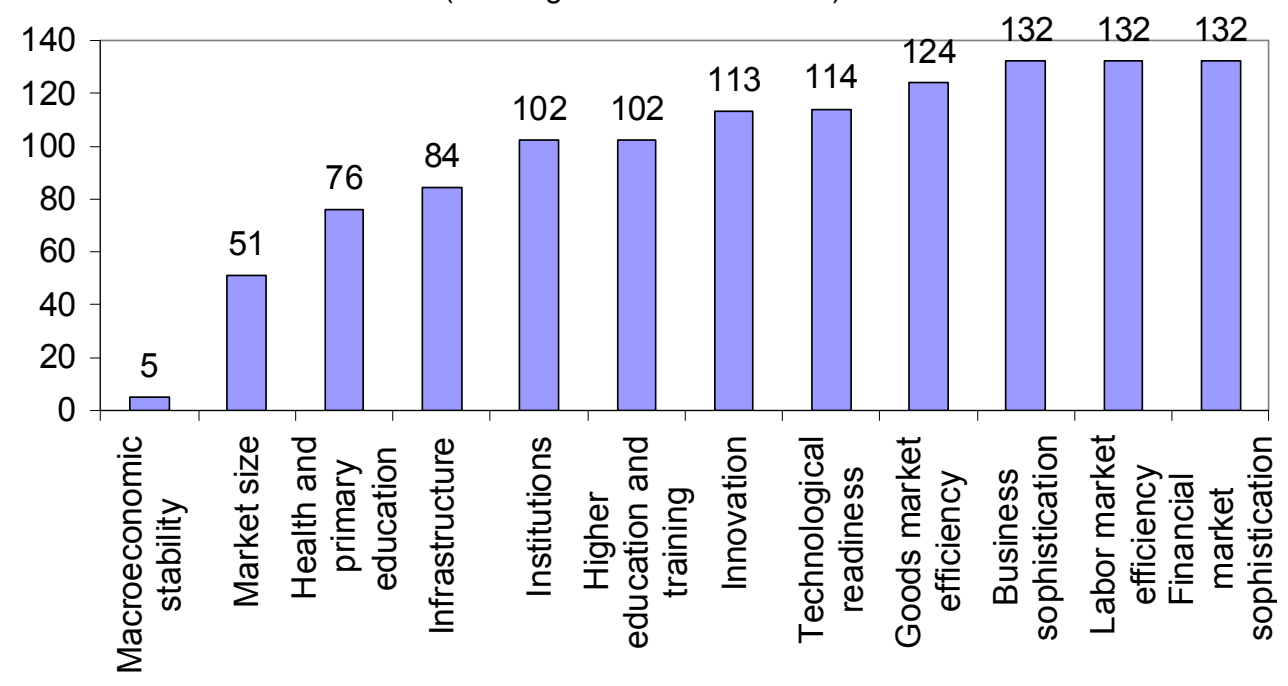

Source: World Economic Forum, 2008.

${ }^{1}$ For details, see IMF Country Reports 08/103 and 08/104. 
program for financial restructuring of public enterprises. ${ }^{9}$ Provisions on loans to public enterprises that this program will free up should go mainly toward increasing bank capital, to shore up the system's lending capacity and its defenses against risk. The 2007 FSAP Update recommended to clarify the role of public banks and prospects for Financial Soundness Indicators reducing state involvement in financial intermediation, further improve the operational environment, and encourage nonbank financing.

\section{Surging imports over the} past few years underscore Algeria's growing openness, but trade with Maghreb partners remains marginal. The regional initiative that started in 2004 to facilitate Maghreb economic integration should help address this issue, and Algeria has played an active role in it. The initiative would help maximize the benefits from implementation of the 2004 (In percent)

\begin{tabular}{lrrr}
\hline & 2005 & 2006 & 2007 \\
\hline Capital adequacy ratio & 12 & 15 & 13 \\
Public banks 1/ & 12 & 14 & 12 \\
Foreign banks 2/ & 19 & 22 & 18 \\
Classified loans/total loans & 36 & 35 & 36 \\
NPLs/total loans 3/ & 19 & 18 & 22 \\
Public banks & 20 & 19 & 24 \\
$\quad$ Of which: private sector & 10 & 12 & 19 \\
Foreign banks & 3 & 3 & 9 \\
Other classified/total loans 4/ & 17 & 17 & 13 \\
Public banks & 18 & 18 & 15 \\
Of which: private sector & 9 & 10 & 6 \\
Foreign banks & 2 & 6 & 2 \\
Provisions/classified loans & 49 & 54 & 55 \\
Public banks & 49 & 54 & 55 \\
Foreign banks & 62 & 49 & 85 \\
Return on equity & 8 & 19 & 25 \\
Public banks & 6 & 17 & 24 \\
Foreign banks & 25 & 23 & 28 \\
\hline
\end{tabular}

Source: Algerian authorities.

$1 / 90$ percent of system assets. 2/ Nonpublic banks are all foreign. 3/ Loans in arrears (100 percent provisioning requirement). 4/ Loans performing but at risk (30 percent or 50 percent provisioning).

EU Association Agreement, notably concerning the development of $\mathrm{NH}$ exports. Algeria also continues negotiations aimed at WTO entry.

\section{Authorities' Views and Policy Intentions}

\section{The financial sector remains at the core of the authorities' reform strategy.}

They are keenly aware that the financial sector needs to be better equipped to finance the economy's investment needs. They emphasized initiatives aimed at increasing the system's lending capacity, including budget appropriations for bank capital and restructuring public enterprises, and agreed with staff on the use of loan provisions. They underscored the increased use of syndication and project finance techniques in relation to large projects, as well as the steady corporate bond issuance and the listing of government bonds on the

\footnotetext{
${ }^{9}$ Public industrial commercial enterprises represent 3 percent of employment. The authorities replaced loans to nonviable enterprises in September 2008 with budgetary support. Financial restructuring of enterprises deemed viable has not yet been implemented. About 2 percent of GDP worth of outstanding loans to public enterprises would be swapped for government bonds under the program, largely replacing the banks' maturing government bonds (see IMF Country Report 08/104).
} 
Algiers stock exchange for better price dissemination. They regretted that shocks to international banks scuppered the bank privatization deal, but still intend to reduce the state's role in financial intermediation. ${ }^{10} \mathrm{BA}$ also indicated that the credit bureau is being extended to household loans, while banks praised the new clearinghouse for retail payments.

30. The authorities are very concerned that Algeria has lost ground in widely publicized rankings of business climate, such as Doing Business or World Economic Forum. They intend to improve the dissemination and communication of their reform achievements, continue streamlining the tax system, and participate in regional integration efforts.

\section{Staff ApPraisal}

\section{Algeria has enjoyed several years of strong economic performance but} continues to face important challenges. Nonhydrocarbon growth has been solid, inflation low, and the fiscal and external positions strong thanks to high hydrocarbon prices. External debt has been virtually eliminated, and the government has accumulated large savings in the FRR. However, youth unemployment remains high, the economy is highly dependent on hydrocarbon exports, the NH private sector is mainly inward oriented, and productivity and business climate are lagging compared to trading partners.

\section{Algeria is largely insulated from direct contagion from the global financial} crisis, but will be affected because of lower oil prices and even more severely if oil prices remain low for an extended period. Algeria's financial system and economy have only limited links to the global financial system. However, low oil prices will significantly depress the external and fiscal positions, and will eventually weigh on growth if they stay low in the medium term.

\section{Staff supports the authorities' fiscal policy stance that maintains the high level} of public spending in the short term, as it will help support $\mathrm{NH}$ growth and mitigate the impact of the global economic downturn. Continuing the implementation of the PIP would improve infrastructure, enhance human capital, and alleviate some social tensions. Large fiscal deficits can be covered in the short term by using the significant savings accumulated in recent years through prudent financial policies. However, staff notes the significant expansion of current expenditure recently, and urges the authorities to limit future increases, particularly in wages and subsidies, to preserve competitiveness and long-term fiscal sustainability. The quality and efficiency of public spending deserve continued intense

\footnotetext{
${ }^{10}$ The much anticipated privatization of a first public bank was cancelled in November 2007 as a result of turmoil affecting the banks that had prequalified. Two foreign banks already operating in Algeria are proceeding with branch network expansions.
} 
scrutiny, and efforts to modernize the budget process, and strengthen fiscal governance should be sustained.

34. Staff encourages the authorities to identify and be ready to implement adjustment fiscal measures in the medium term to preserve fiscal sustainability. A careful assessment of public expenditures is needed to identify savings. Measures could include better control of current expenditure, prioritization of investment projects, and enhanced nonhydrocarbon tax collection. Fiscal policy may need to be adjusted as early as 2009 if risks of durably low oil prices materialize. In this event, the authorities could start rationalizing current expenditure, including by reducing subsidies.

35. The central bank has been able to contain inflationary pressures, but should now stand ready to ease monetary policy, if necessary, to sustain domestic demand. Monetary policy has succeeded in absorbing the banking system's structural liquidity surplus and limiting its impact on inflation. The decline in import prices should create room for reducing interest rates, if needed, as a complement to fiscal policy.

36. BA should continue to pursue an exchange rate policy consistent with external stability. The real effective exchange rate of the dinar has remained close to its equilibrium level. The authorities should continue to monitor developments closely to minimize the risk of misalignment, and may seek to reduce the short-term volatility of the nominal effective exchange rate.

\section{Staff urges the authorities to accelerate structural reforms to boost the supply} response to the massive PIP. The global crisis highlights the importance of economic diversification to mitigate hydrocarbon risk. Private sector investment and NH exports must increasingly replace public investment as the engine of growth. This requires major gains in productivity through continued macroeconomic stability, and better infrastructure, human capital, and public services. At the same time, and as the major PIP projects are progressively completed, the authorities need to renew their focus on structural reforms to achieve effective financial intermediation, promote privatization, improve the business climate, and deepen the integration in the regional and world economies. Staff encourages the authorities to implement the recommendations of the 2007 FSAP Update. Staff also reminds the authorities that public guarantee schemes for SME credit should not undermine the banks' efforts to bolster risk analysis.

38. Staff encourages the authorities to expedite Algeria's participation as a creditor in the Enhanced HIPC Initiative.

39. It is proposed that the next Article IV consultation with Algeria take place on a standard 12-month cycle. Staff stands ready in the meantime to maintain a close dialogue with the authorities in view of the volatile global environment. 
Table 1. Algeria: Selected Economic and Financial Indicators, 2005-13

\begin{tabular}{|c|c|c|c|c|c|c|c|c|c|}
\hline & \multirow[b]{2}{*}{2005} & \multirow[b]{2}{*}{2006} & \multirow[b]{2}{*}{2007} & \multirow[b]{2}{*}{2008} & \multicolumn{3}{|c|}{ Projections } & \multirow[b]{2}{*}{2012} & \multirow[b]{2}{*}{2013} \\
\hline & & & & & 2009 & 2010 & 2011 & & \\
\hline & \multicolumn{9}{|c|}{ (Annual percentage change; unless otherwise indicated) } \\
\hline \multicolumn{10}{|l|}{ Oil and gas sector } \\
\hline Liquid petroleum exports (in millions of barrels/day) & 1.8 & 1.7 & 1.7 & 1.6 & 1.6 & 1.6 & 1.6 & 1.6 & 1.6 \\
\hline Natural gas exports (in billions of $\mathrm{m} 3$ ) & 64.0 & 61.8 & 59.4 & 61.7 & 60.1 & 59.4 & 59.1 & 59.3 & 60.2 \\
\hline Crude oil export unit value (US\$/bbl) & 54.6 & 65.7 & 74.7 & 99.4 & 54.3 & 64.8 & 71.3 & 75.0 & 77.5 \\
\hline Share of hydrocarbons in total exports (in percent) & 98.3 & 97.9 & 98.4 & 98.5 & 97.2 & 97.5 & 97.5 & 97.5 & 96.7 \\
\hline \multicolumn{10}{|l|}{ National income and prices } \\
\hline GDP at constant prices 1/ & 5.1 & 2.0 & 3.0 & 3.0 & 2.6 & 3.9 & 3.9 & 4.1 & 4.4 \\
\hline Hydrocarbon sector & 5.8 & -2.5 & -0.9 & -0.6 & -1.0 & 0.0 & 0.7 & 1.5 & 2.3 \\
\hline Other sectors & 4.7 & 5.6 & 6.3 & 5.8 & 6.0 & 5.8 & 5.6 & 5.5 & 5.5 \\
\hline Consumer price index (end of period) & 1.7 & 4.4 & 3.9 & 4.0 & 3.5 & 3.3 & 3.2 & 3.1 & 3.0 \\
\hline \multicolumn{10}{|l|}{ External sector $2 /$} \\
\hline Exports, f.o.b. & 43.8 & 18.2 & 10.7 & 29.1 & -43.3 & 17.5 & 9.4 & 5.7 & 5.7 \\
\hline Hydrocarbons & 44.3 & 17.7 & 11.2 & 29.2 & -44.0 & 17.8 & 9.5 & 5.7 & 4.9 \\
\hline Nonhydrocarbons & 17.9 & 43.0 & -13.3 & 22.4 & 4.6 & 5.8 & 6.4 & 6.4 & 39.6 \\
\hline Imports, f.o.b. & 10.6 & 4.1 & 27.4 & 37.6 & 11.4 & 10.6 & 7.9 & 4.9 & 4.6 \\
\hline Current account balance (in percent of GDP) & 20.6 & 25.2 & 22.6 & 20.2 & -2.9 & -0.9 & -1.0 & -1.3 & -1.5 \\
\hline \multicolumn{10}{|l|}{ Money and credit } \\
\hline Net foreign assets & 34.0 & 31.9 & 34.5 & 19.6 & 4.9 & $\ldots$ & $\ldots$ & $\ldots$ & $\ldots$ \\
\hline Domestic credit $3 /$ & -17.8 & -5.9 & -11.9 & -17.0 & 16.3 & $\ldots$ & $\ldots$ & $\ldots$ & $\ldots$ \\
\hline Credit to the government (net) $3 / 4 /$ & -24.4 & -8.9 & -18.0 & -23.0 & 11.1 & $\ldots$ & $\ldots$ & $\ldots$ & $\ldots$ \\
\hline Credit to the economy 4 / & 15.9 & 7.1 & 15.7 & 16.1 & 13.8 & $\ldots$ & $\ldots$ & $\ldots$ & ... \\
\hline Money and quasi-money & 11.7 & 18.6 & 24.2 & 13.2 & 10.9 & $\ldots$ & $\ldots$ & $\ldots$ & $\ldots$ \\
\hline Velocity of broad money (GDP/M2) & 1.9 & 1.8 & 1.6 & 1.7 & 1.3 & $\ldots$ & $\ldots$ & $\ldots$ & $\ldots$ \\
\hline \multirow[t]{2}{*}{ Idem, in percent of nonhydrocarbon GDP } & 1.0 & 0.9 & 0.9 & 0.9 & 0.8 & $\ldots$ & $\ldots$ & $\ldots$ & ... \\
\hline & \multicolumn{9}{|c|}{ (In percent of GDP) } \\
\hline Saving-investment balance & 20.6 & 25.2 & 22.6 & 20.2 & -2.9 & -0.9 & -1.0 & -1.3 & -1.5 \\
\hline National savings & 51.8 & 54.9 & 57.2 & 55.5 & 43.6 & 47.6 & 45.6 & 43.4 & 41.5 \\
\hline Government & 22.6 & 25.6 & 20.0 & 23.9 & 7.8 & 9.4 & 9.9 & 9.6 & 9.1 \\
\hline Of which: Nongovernment & 29.2 & 29.2 & 37.2 & 31.5 & 35.9 & 38.2 & 35.7 & 33.7 & 32.3 \\
\hline Investment & 31.2 & 29.7 & 34.6 & 35.2 & 46.6 & 48.5 & 46.6 & 44.7 & 43.0 \\
\hline Of which: Nongovernment & 20.4 & 17.6 & 19.1 & 19.5 & 27.3 & 30.5 & 29.4 & 29.1 & 28.6 \\
\hline Central government finance & & & & & & & & & \\
\hline Overall budget balance (deficit-) & 11.9 & 13.6 & 4.5 & 8.2 & -11.5 & -8.6 & -7.3 & -5.9 & -5.2 \\
\hline & & & $(\ln r$ & cent of & nhydro & arbon GD & & & \\
\hline Central government finance & & & & & & & & & \\
\hline Total revenue & 73.6 & 79.5 & 70.7 & 86.2 & 52.6 & 54.6 & 54.6 & 53.4 & 52.1 \\
\hline Hydrocarbon & 56.1 & 61.1 & 53.6 & 68.6 & 34.7 & 36.9 & 37.1 & 36.1 & 34.9 \\
\hline Nonhydrocarbon & 17.4 & 18.4 & 17.1 & 17.7 & 17.9 & 17.7 & 17.6 & 17.4 & 17.2 \\
\hline Total expenditure & 52.2 & 54.4 & 62.7 & 70.4 & 69.7 & 67.8 & 65.8 & 62.5 & 60.1 \\
\hline Current expenditure & 29.6 & 31.3 & 31.9 & 40.3 & 41.0 & 40.2 & 39.4 & 38.7 & 38.2 \\
\hline Capital expenditure & 19.3 & 23.1 & 30.7 & 30.1 & 28.7 & 27.6 & 26.5 & 23.8 & 21.9 \\
\hline Nonhydrocarbon primary balance & -33.0 & -34.5 & -44.0 & -52.1 & -51.4 & -49.7 & -47.9 & -44.7 & -42.5 \\
\hline Memorandum items: & & & & & & & & & \\
\hline GDP (in billions of dinars at current prices) & 7544 & 8461 & 9306 & 11230 & 9436 & 10538 & 11532 & 12433 & 13352 \\
\hline GDP (in billions of US\$ current prices) & 102.7 & 116.8 & 135.3 & 162.9 & 134.8 & 152.7 & 167.1 & 180.2 & 193.5 \\
\hline Per capita GDP (in US\$) & 3122 & 3456 & 3934 & 4681 & 3816 & 4260 & 4593 & 4879 & 5162 \\
\hline Gross official reserves (end of period) & 56.2 & 77.8 & 110.2 & 138.9 & 134.4 & 132.8 & 131.2 & 129.0 & 126.5 \\
\hline In months of next year's imports of goods and services & 26.5 & 28.0 & 27.4 & 31.0 & 27.1 & 24.8 & 23.4 & 22.0 & 20.6 \\
\hline Gross government debt (in percent of GDP) & 27.3 & 23.8 & 11.9 & 6.5 & 7.7 & 6.9 & 6.3 & 5.8 & 5.5 \\
\hline Total external debt (in percent of GDP) & 16.7 & 4.8 & 3.8 & 3.0 & 3.4 & 3.0 & 2.7 & 2.6 & 2.4 \\
\hline Nominal effective exchange rate $5 /$ & -2.8 & 0.2 & -1.8 & -0.1 & $\ldots$ & $\ldots$ & $\ldots$ & $\ldots$ & $\ldots$ \\
\hline Real effective exchange rate (percent change) 5/ & -4.0 & 0.0 & -1.0 & -1.2 & $\ldots$ & $\ldots$ & $\ldots$ & $\ldots$ & $\ldots$ \\
\hline Exchange rate (DA/US\$) (end of period) 6/ & 73.4 & 71.2 & 66.8 & 71.2 & $\ldots$ & $\ldots$ & $\ldots$ & $\ldots$ & $\ldots$ \\
\hline Population (in millions) & 32.9 & 33.8 & 34.4 & $\ldots$ & $\ldots$ & $\ldots$ & $\ldots$ & $\ldots$ & $\ldots$ \\
\hline Unemployment rate (in percent) $7 /$ & 15.3 & 12.3 & 11.8 & $\ldots$ & $\ldots$ & $\ldots$ & $\ldots$ & $\ldots$ & $\ldots$ \\
\hline & & & & & & & & & \\
\hline $\begin{array}{l}\text { 1/ In constant } 2001 \text { prices. } \\
2 / \text { In U.S. dollars terms. } \\
3 / \text { In percent of beginning money stock. } \\
4 \text { / Including the impact of the financial restructuring in } 20 \\
5 / \text { Annual average changes in trade-weighted INS index. } \\
6 \text { / For } 2008 \text {, as of December } 3 \text {. }\end{array}$ & $\begin{array}{l}\text { Dlving } \\
\text { rease }\end{array}$ & lies a & $\begin{array}{l}\text { over } \\
\text { recia }\end{array}$ & For 2 & $\begin{array}{l}r \text { ban } \\
\text { as of }\end{array}$ & ims & blic e & ses. & \\
\hline
\end{tabular}


Table 2. Algeria: Balance of Payments, 2005-13

(In billions of U.S. dollars; unless otherwise indicated)

\begin{tabular}{|c|c|c|c|c|c|c|c|c|c|}
\hline & \multirow[b]{2}{*}{2005} & \multirow[b]{2}{*}{2006} & \multirow[b]{2}{*}{2007} & \multicolumn{6}{|c|}{ Projections } \\
\hline & & & & 2008 & 2009 & 2010 & 2011 & 2012 & 2013 \\
\hline Current account & 21.2 & 29.0 & 30.6 & 32.9 & -4.0 & -1.4 & -1.6 & -2.4 & -2.9 \\
\hline Trade balance & 26.5 & 34.1 & 34.2 & 42.0 & 4.0 & 7.5 & 8.8 & 9.7 & 10.9 \\
\hline Exports, f.o.b. & 46.3 & 54.7 & 60.6 & 78.2 & 44.4 & 52.2 & 57.1 & 60.3 & 63.8 \\
\hline Hydrocarbons & 45.5 & 53.6 & 59.6 & 77.0 & 43.1 & 50.8 & 55.7 & 58.8 & 61.7 \\
\hline Other & 5.7 & -2.8 & -1.6 & -1.9 & -2.5 & -1.3 & -0.5 & 0.4 & 1.5 \\
\hline Price change in percent & 36.6 & 21.0 & 12.9 & 31.9 & -42.6 & 19.4 & 10.1 & 5.3 & 3.3 \\
\hline Other & 0.8 & 1.1 & 1.0 & 1.2 & 1.3 & 1.3 & 1.4 & 1.5 & 2.1 \\
\hline Imports, f.o.b. & -19.9 & -20.7 & -26.4 & -36.3 & -40.4 & -44.7 & -48.2 & -50.6 & -52.9 \\
\hline Volume change in percent & 6.3 & -5.7 & 14.0 & 20.2 & 18.6 & 8.9 & 6.5 & 3.8 & 3.5 \\
\hline Price change in percent & 4.1 & 10.4 & 11.8 & 14.4 & -6.1 & 1.6 & 1.4 & 1.0 & 1.1 \\
\hline Services and income (net) & -7.4 & -6.7 & -5.9 & -11.2 & -10.2 & -11.3 & -12.9 & -14.6 & -16.4 \\
\hline Services (net) & -2.3 & -2.2 & -4.0 & -8.3 & -10.5 & -11.6 & -12.5 & -13.1 & -13.7 \\
\hline Credit & 2.5 & 2.6 & 2.9 & 3.7 & 3.0 & 3.3 & 3.5 & 3.7 & 3.9 \\
\hline Debit & -4.8 & -4.8 & -6.9 & -12.0 & -13.4 & -14.8 & -16.0 & -16.8 & -17.6 \\
\hline Income (net) & -5.1 & -4.5 & -1.8 & -2.9 & 0.2 & 0.3 & -0.4 & -1.6 & -2.8 \\
\hline Credit & 1.4 & 2.4 & 3.8 & 4.5 & 5.6 & 7.2 & 7.7 & 7.6 & 7.4 \\
\hline Debit & -6.5 & -6.9 & -5.6 & -7.4 & -5.4 & -6.9 & -8.1 & -9.1 & -10.2 \\
\hline Interest payments & -1.0 & -0.8 & -0.2 & -0.2 & -0.2 & -0.2 & -0.2 & -0.2 & -0.2 \\
\hline Other, including profit repatriation & -5.5 & -6.2 & -5.4 & -7.2 & -5.2 & -6.7 & -7.9 & -8.9 & -10.0 \\
\hline Transfers (net) & 2.1 & 1.6 & 2.2 & 2.2 & 2.3 & 2.4 & 2.5 & 2.5 & 2.6 \\
\hline Capital account & -4.2 & -11.2 & -1.1 & -0.9 & -0.9 & -0.5 & -0.3 & -0.1 & 0.2 \\
\hline Medium- and long-term capital & -2.0 & -10.1 & 0.6 & 0.7 & 0.8 & 1.1 & 1.3 & 1.6 & 1.8 \\
\hline Direct investment (net) & 1.1 & 1.8 & 1.4 & 1.0 & 1.0 & 1.2 & 1.3 & 1.5 & 1.8 \\
\hline Loans (net) & -3.1 & -11.9 & -0.8 & -0.3 & -0.2 & -0.1 & 0.0 & 0.0 & 0.0 \\
\hline Drawings & 1.4 & 1.0 & 0.5 & 0.9 & 1.0 & 1.1 & 1.1 & 1.2 & 1.2 \\
\hline Amortization & -4.5 & -12.9 & -1.3 & -1.2 & -1.2 & -1.1 & -1.1 & -1.2 & -1.1 \\
\hline Short-term capital and errors and omissions & -2.2 & -1.1 & -1.7 & -1.7 & -1.7 & -1.7 & -1.7 & -1.7 & -1.7 \\
\hline Overall balance & 16.9 & 17.7 & 29.6 & 32.0 & -4.8 & -2.0 & -1.9 & -2.4 & -2.8 \\
\hline Financing & -16.9 & -17.7 & -29.6 & -32.0 & 4.8 & 2.0 & 1.9 & 2.4 & 2.8 \\
\hline Official reserves (increases -) & -16.3 & -17.7 & -29.6 & -32.0 & 4.8 & 2.0 & 1.9 & 2.4 & 2.8 \\
\hline \multicolumn{10}{|l|}{ Memorandum items: } \\
\hline Current account balance (in percent of GDP) & 20.6 & 25.2 & 22.6 & 20.2 & -2.9 & -0.9 & -1.0 & -1.3 & -1.5 \\
\hline Algerian crude oil price (US\$/barrel) $1 /$ & 54.6 & 65.7 & 74.7 & 99.4 & 54.3 & 64.8 & 71.3 & 75.0 & 77.5 \\
\hline Gross official reserves (in billions of US\$) & 56.2 & 77.8 & 110.2 & 138.9 & 134.4 & 132.8 & 131.2 & 129.0 & 126.5 \\
\hline Idem, in months of next year's imports & 26.5 & 28.0 & 27.4 & 31.0 & 27.1 & 24.8 & 23.4 & 22.0 & 20.6 \\
\hline Gross external debt (in billions of US\$) & 17.2 & 5.6 & 5.1 & 4.8 & 4.6 & 4.6 & 4.6 & 4.6 & 4.7 \\
\hline Of which: Short term & 0.7 & 0.6 & 0.7 & $\ldots$ & $\ldots$ & $\ldots$ & $\ldots$ & $\ldots$ & $\cdots$ \\
\hline External debt/exports (in percent) & 35.2 & 9.8 & 8.1 & 5.9 & 9.8 & 8.3 & 7.6 & 7.2 & 6.9 \\
\hline External debt/GDP (in percent) & 16.7 & 4.9 & 3.8 & 3.0 & 3.4 & 3.0 & 2.7 & 2.6 & 2.4 \\
\hline
\end{tabular}

Sources: Algerian authorities; and Fund staff estimates and projections. 
Table 3. Algeria: Summary of Central Government Operations, 2005-13 1/

\begin{tabular}{|c|c|c|c|c|c|c|c|c|c|}
\hline & \multirow[b]{2}{*}{2005} & \multirow[b]{2}{*}{2006} & \multirow{2}{*}{$\frac{\text { Prel. }}{2007}$} & \multicolumn{6}{|c|}{ Projections } \\
\hline & & & & 2008 & 2009 & 2010 & 2011 & 2012 & 2013 \\
\hline \multicolumn{10}{|c|}{ (In billions of Algerian dinars) } \\
\hline Budget revenue and grants & 3083 & 3640 & 3688 & 5050 & 3332 & 3759 & 4087 & 4335 & 4579 \\
\hline Hydrocarbon revenue 2/ & 2353 & 2799 & 2797 & 4015 & 2199 & 2540 & 2774 & 2927 & 3066 \\
\hline Nonhydrocarbon revenue & 730 & 841 & 891 & 1035 & 1133 & 1219 & 1314 & 1408 & 1512 \\
\hline Tax revenue & 640 & 721 & 767 & 899 & 988 & 1069 & 1154 & 1239 & 1331 \\
\hline Nontax revenues & 90 & 120 & 124 & 136 & 145 & 150 & 159 & 169 & 182 \\
\hline Total expenditure & 2052 & 2453 & 3109 & 4124 & 4417 & 4668 & 4927 & 5066 & 5277 \\
\hline Current expenditure & 1241 & 1434 & 1666 & 2361 & 2599 & 2768 & 2947 & 3136 & 3357 \\
\hline Personnel expenditure & 492 & 531 & 629 & 818 & 941 & 1000 & 1058 & 1119 & 1183 \\
\hline Mudjahidins' pensions & 80 & 93 & 102 & 105 & 109 & 108 & 106 & 104 & 102 \\
\hline Material and supplies & 76 & 96 & 94 & 125 & 153 & 178 & 206 & 235 & 266 \\
\hline Current transfers & 520 & 646 & 762 & 1276 & 1365 & 1453 & 1547 & 1648 & 1778 \\
\hline Interest payments & 73 & 69 & 80 & 36 & 31 & 29 & 29 & 29 & 29 \\
\hline Capital expenditure & 811 & 1019 & 1442 & 1763 & 1819 & 1900 & 1980 & 1930 & 1920 \\
\hline Budget balance & 1031 & 1187 & 579 & 925 & -1085 & -908 & -839 & -731 & -698 \\
\hline Special accounts & -129 & -4 & -19 & 0 & 0 & 0 & 0 & 0 & 0 \\
\hline Net lending by the treasury & 5 & 32 & 141 & 0 & 0 & 0 & 0 & 0 & 0 \\
\hline Nonhydrocarbon balance & -1456 & -1648 & -2378 & -3089 & -3284 & -3449 & -3613 & -3658 & -3765 \\
\hline Overall balance & 897 & 1151 & 419 & 925 & -1085 & -908 & -839 & -731 & -698 \\
\hline Financing & -897 & -1151 & -419 & -925 & 1085 & 908 & 839 & 731 & 698 \\
\hline Domestic & -781 & -992 & -308 & -903 & 1103 & 925 & 852 & 743 & 711 \\
\hline \multirow[t]{2}{*}{ Foreign } & -116 & -159 & -111 & -22 & -18 & -17 & -13 & -12 & -12 \\
\hline & \multicolumn{8}{|c|}{ (In percent of GDP) } & \\
\hline Total revenue & 40.9 & 43.0 & 39.6 & 45.0 & 35.3 & 35.7 & 35.4 & 34.9 & 34.3 \\
\hline Total expenditure & 29.0 & 29.4 & 35.1 & 36.7 & 46.8 & 44.3 & 42.7 & 40.7 & 39.5 \\
\hline Current expenditure & 16.5 & 16.9 & 17.9 & 21.0 & 27.5 & 26.3 & 25.6 & 25.2 & 25.1 \\
\hline Capital expenditure & 10.7 & 12.5 & 17.2 & 15.7 & 19.3 & 18.0 & 17.2 & 15.5 & 14.4 \\
\hline \multirow[t]{2}{*}{ Overall balance } & 11.9 & 13.6 & 4.5 & 8.2 & -11.5 & -8.6 & -7.3 & -5.9 & -5.2 \\
\hline & \multicolumn{8}{|c|}{ (In percent of nonhydrocarbon GDP) } & \\
\hline Total revenue & 73.6 & 79.5 & 70.7 & 86.2 & 52.6 & 54.6 & 54.6 & 53.4 & 52.1 \\
\hline Hydrocarbon revenue & 56.1 & 61.1 & 53.6 & 68.6 & 34.7 & 36.9 & 37.1 & 36.1 & 34.9 \\
\hline Nonhydrocarbon revenue & 17.4 & 18.4 & 17.1 & 17.7 & 17.9 & 17.7 & 17.6 & 17.4 & 17.2 \\
\hline Of which: Tax revenue & 15.3 & 15.7 & 14.7 & 15.4 & 15.6 & 15.5 & 15.4 & 15.3 & 15.2 \\
\hline Total expenditure & 52.2 & 54.4 & 62.7 & 70.4 & 69.7 & 67.8 & 65.8 & 62.5 & 60.1 \\
\hline Current expenditure & 29.6 & 31.3 & 31.9 & 40.3 & 41.0 & 40.2 & 39.4 & 38.7 & 38.2 \\
\hline Capital expenditure & 19.3 & 23.1 & 30.7 & 30.1 & 28.7 & 27.6 & 26.5 & 23.8 & 21.9 \\
\hline Other & 3.2 & 0.0 & 0.0 & 0.0 & 0.0 & 0.0 & 0.0 & 0.0 & 0.0 \\
\hline Other (previous numbers) & 3.2 & 0.8 & 3.1 & 0.0 & 0.0 & 0.0 & 0.0 & 0.0 & 0.0 \\
\hline Nonhydrocarbon primary balance & -33.0 & -34.5 & -44.0 & -52.1 & -51.4 & -49.7 & -47.9 & -44.7 & -42.5 \\
\hline Nonhydrocarbon overall balance & -34.7 & -36.0 & -45.6 & -52.8 & -51.9 & -50.1 & -48.3 & -45.1 & -42.9 \\
\hline
\end{tabular}

Sources: Algerian authorities; and Fund staff estimates and projections.

1/ On cash basis.

2/ Including dividends of Sonatrach. 
Table 4. Algeria: Monetary Survey, 2005-09



Sources: Bank of Algeria; and Fund staff estimates and projections.

$1 /$ Includes impact of public banks' restructuring packages.

2/ Net credit to government excludes postal accounts ("dépôts CCP").

3 / Includes postal accounts ("dépôts CCP") at the treasury. 
ANNEX I. RELATIONS WITH THE FUND

(As of November 30, 2008)

\section{A. Financial Relations}

Membership Status Joined 9/26/63; Article VIII

General Resources Account

Quota

Fund holdings of currency

Reserve position in Fund

\section{SDR Department}

Net cumulative allocation

Holdings

\section{SDR Million}

$1,254.70$

$1,169.62$

85.08

SDR Million

128.64

6.46
Percent of Quota

100.00

93.22

6.78

\section{Percent of}

Allocation

100.00

5.02

Outstanding Purchases and Loans: None.

Financial Arrangements

$\begin{array}{lcccc}\text { Type } & \begin{array}{c}\text { Approval } \\ \text { Date }\end{array} & \begin{array}{c}\text { Expiration } \\ \text { Date }\end{array} & \begin{array}{c}\text { Amount } \\ \text { Approved } \\ \text { (SDR Million) }\end{array} & \begin{array}{c}\text { Amount } \\ \text { Drawn } \\ \text { (SDR Million) }\end{array} \\ \text { EFF } & 5 / 22 / 95 & 5 / 21 / 98 & 1,169.28 & 1,169.28 \\ \text { Stand-by } & 5 / 27 / 94 & 5 / 22 / 95 & 457.20 & 385.20 \\ \text { Stand-by } & 6 / 03 / 91 & 3 / 31 / 92 & 300.00 & 225.00\end{array}$

\section{Projected Obligations to Fund}

(SDR million; based on existing use of resources and present holdings of SDRs)

\begin{tabular}{lcccccc}
\hline & Overdue & \multicolumn{5}{c}{ Forthcoming } \\
& & 2008 & 2009 & 2010 & 2011 & 2012 \\
\hline Principal & 0.00 & 0.00 & 0.00 & 0.00 & 0.00 & 0.00 \\
Charges/interest & 0.00 & 0.81 & 1.31 & 1.28 & 1.28 & 1.28 \\
Total & 0.00 & 0.81 & 1.31 & 1.28 & 1.28 & 1.28 \\
\hline
\end{tabular}

\section{Implementation of HIPC Initiative: Not Applicable.}




\section{B. Nonfinancial Relations}

\section{Exchange Rate Arrangement}

1. From January 21, 1974 to October 1, 1994, the exchange rate of the dinar was determined on the basis of a fixed relationship with a basket of currencies, adjusted from time to time. On October 1, 1994, the Bank of Algeria introduced a managed float for the dinar through daily fixing sessions that included six commercial banks. This system has been replaced by an interbank foreign exchange market as of January 2, 1996. On December 22, 2008, the average of the buying and selling rates for the U.S. dollar was $\$ 1=$ DA 71.2, equivalent to SDR 1 = DA 109.9. No margin limits are imposed on the buying and selling exchange rates in the interbank foreign exchange market, except for a margin of DA 0.017 between the buying and selling rates of the Bank of Algeria for the dinar against the U.S. dollar.

2. The exchange regime is a managed float with no preannounced path for the exchange rate. Full surrender requirements are in effect on hydrocarbon export proceeds. Limits on the making of payments for invisible transactions and current transfers, which have remained since Algeria accepted the obligations of Article VIII, sections 2(a), 3, and 4, in 1997, are indicative according to the authorities. Inward direct investment is generally free of restrictions; controls are maintained on other capital account payments and transfers.

\section{Latest Article IV Consultation}

The discussions for the 2007 Article IV consultation with Algeria were held in Algiers during November 4-21, 2007. The staff report (IMF Country Report No. 08/103) was discussed by the Executive Board on February 11, 2008 and published on March 17, 2008.

\section{Technical Assistance}

- An MFD expert visited Algiers in January-February 2005 to advise on bank inspection.

- An STA expert visited Algiers in June-July 2005 to advise on the development of quarterly national accounts statistics.

- An MFD mission visited Algiers in July 2005 to advise on liquidity management and monetary operations.

- An MFD/LEG mission visited Algiers in July 2005 to advise on the exchange regime and the development of the foreign exchange market.

- An MFD expert visited Algiers in October 2005 to advise on foreign exchange reserve management.

- An MFD mission visited Algiers in September 2005, December 2005, and in May 2006 
to advise on bank restructuring.

- An MFD expert visited Algiers several times from February through September 2006 to assist the Bank of Algeria to develop its bank supervision and regulation capability.

- An MFD expert visited Algiers in January-February 2006 to advise on monetary and foreign exchange operations.

- An MFD expert visited Algiers in February and May 2006 to advise on foreign exchange reserve management.

- A STA mission visited Algiers in May 2006 to advise on monetary and financial statistics.

- An MFD expert visited Algiers in May 2006 to advise on payment systems.

- A STA mission visited Algiers in May 2006 to advise on consumer price statistics.

- MFDs expert visited Algiers several times from February through October 2007 to assist the Bank of Algeria in banking supervision.

- Two FAD missions visited Algiers in February 2007 to review tax policy and advise on customs administration.

- A multisector STA mission visited Algiers in February 2007 to prepare Algeria's participation in the GDDS.

- An FAD mission visited Algiers in April 2007 to continue the program of assistance in tax administration.

- An FAD mission visited Algiers in May 2008 to continue the program of assistance in tax administration.

\section{Financial Sector Assessment Program}

Algeria participated in the FSAP in 2003. The Executive Board discussed the Financial System Stability Assessment on January 14, 2004, (see IMF Country Report No. 04/138). The FSAP was updated in 2007.

\section{Resident Representative/Advisor}

None. 


\section{ANNEX II. RELATIONS WITH THE WORLD BANK}

(As of September 30, 2008)

The Algeria Country Assistance Strategy for 2004-06 aimed at: (a) strengthening fiscal sustainability and hydrocarbon revenue management to build the basis for sustained growth; (b) removing the constraints to private sector-led growth, particularly those affecting the business environment, SMEs, the financial sector, and infrastructure development; and (c) supporting the government's efforts to articulate and implement a strategy for better service delivery, particularly in water supply, transport, housing, environmental services and human development to meet the critical needs of the population. The Bank Group's support is guided by three principles: (a) selectivity through engagement in a limited number of areas and a selective use of Bank instruments; (b) programmatic approaches focused on transfer of knowledge and capacity building; and (c) partnerships, outreach and knowledge sharing. Preparation of a new Country Partnership Strategy between Algeria and the Bank for FY09 and beyond has been launched. In the absence of new borrowing by Algeria, this strategy is expected to concentrate on technical assistance and analytical activities, in priority areas.

The World Bank portfolio in Algeria comprises 1 active operation and 72 closed loans, with cumulative net commitment of $\$ 4.3$ billion, of which $\$ 4.2$ billion have been repaid. Net commitments for the current operation amount to \$18.4 million of which \$6.5 million have been disbursed. This operation is scheduled to close on February 28, 2009. No new loans have been approved since FY03. In FY06 the government prepaid \$637 million of 22 IBRD loans, and cancelled $\$ 176.9$ million of loans for active operations.

Recent analytical work concluded includes an update of the FSAP carried out jointly with the IMF, a Public Expenditure Review (PER) also done in collaboration with the IMF and under wide public dissemination; a Labor Markets and Social Protection policy note; a second Investment Climate Assessment; and a policy note on Trade in Services. Recent technical assistance (TA) has supported social insurance, specifically in the area of pensions; macroeconomic modeling to the Ministry of Finance and the Central Bank; improvement of the doing business indicators; training in analytical tools for poverty, governance and private sector development issues to Conseil National Economique et Social (CNES); training in rural development topics; and training in skills development and technical, vocational and educational.

Starting in 2006, the authorities expressed interest in Reimbursable Technical Assistance (RTA) from the World Bank. Ongoing RTA activities include: assistance to the Ministry of Urban Planning and Environment (MATE) in the area of solid waste management and the rehabilitation of open dumps and clean development mechanism; advisory services on procurement to SONATRACH; and assistance to the Central Bank for the creation of a credit bureau and on the regulatory framework of credit cooperatives. Two technical assistance activities were completed recently: preparation of management contracts in water supply for three of the largest cities; and capacity building for the Caisse Nationale d'Equipement et de Développement (CNED). 


\section{Algeria: Financial Relations with the World Bank}

(As of September 30, 2008)

\begin{tabular}{|c|c|c|c|c|c|c|}
\hline \multirow{2}{*}{ IBRD lending operations 1 / } & \multicolumn{3}{|c|}{$\begin{array}{c}\text { Total Net } \\
\text { Commitments }\end{array}$} & \multicolumn{3}{|c|}{$\begin{array}{r}\text { Undisbursed } \\
\text { Balance }\end{array}$} \\
\hline & \multicolumn{6}{|c|}{ (In millions of U.S. dollars) } \\
\hline 72 loans closed 2/ & \multicolumn{3}{|c|}{$4,299.6$} & & & \\
\hline $\begin{array}{l}1 \text { active loan: } \\
\text { - Budget System Modernization }\end{array}$ & \multicolumn{3}{|c|}{18.4} & & & 11.9 \\
\hline $\begin{array}{l}\text { Total active loans } \\
\text { Repayments } \\
\text { Debt outstanding }\end{array}$ & \multicolumn{3}{|c|}{$\begin{array}{r}18.4 \\
4,163.0 \\
106.8\end{array}$} & & \multicolumn{2}{|r|}{11.9} \\
\hline \multirow{2}{*}{\multicolumn{7}{|c|}{$\begin{array}{l}\text { Net lending by the World } \\
\text { Bank (by fiscal year) 3/ }\end{array}$}} \\
\hline & & & & & & \\
\hline Commitments & 0 & 0 & 0 & 0 & 0 & 0 \\
\hline Disbursements & 51 & 27 & 29 & 7 & 6 & 0 \\
\hline Debt service & 270 & 224 & 789 & 18 & 22 & 3 \\
\hline Principal & 197 & 174 & 748 & 11 & 16 & 3 \\
\hline Interest 4/ & 73 & 50 & 41 & 6 & 6 & 0 \\
\hline Net transfer $5 /$ & -219 & -197 & -760 & -11 & -16 & -3 \\
\hline
\end{tabular}

1/ IDA has no operations in Algeria.

2/ Less cancellations, includes adjustment lending.

3/ Fiscal years start July 1 and end June 30 .

4/ Includes charges.

5/ Equal to disbursements minus debt service. 


\section{ANNEX III. ALGERIA: STATISTICAL ISSUES}

Data provision to the Fund has some shortcomings, but is broadly adequate for surveillance. Government finance statistics, national accounts, and prices have various shortcomings that hamper analysis.

Algeria initiated participation in the General Data Dissemination System (GDDS) in February 2006, but has yet to complete the preparation of metadata and plans for improving the statistical system.

\section{Real Sector Statistics}

Key shortcomings in national accounts are: old base GDP series, long lags for publication of data, and incomplete application of the 1993 System of National Accounts. STA has recommended giving priority to compiling GDP at constant prices (including quarterly accounts) and to rebasing the GDP series. STA also recommended that the Banque d'Algerie (BA) and the Ministère des Finances (MF) assume some tasks currently assigned to the ONS in order to reduce its workload.

The monthly consumer price index (CPI) is based on outdated basket of products and weights derived from a 1988 survey of household consumption and is published with a delay of about 3 months. However, a new CPI with an updated basket of products and weights is near completion and will be released in 2009 .

\section{Government Finance Statistics (GFS)}

Key shortcomings include: insufficient institutional coverage (coverage is limited to Budgetary Central Government, albeit in a wide sense, including the general budget, the annexed budget, and the special treasury accounts); classification problems (proceeds of the oil stabilization fund (FRR) should be shown as revenue rather than financing); long lags for production of statistics; and lack of reconciliation of financing with the monetary accounts. Key factors behind these weaknesses include the lack of financial resources allocated to the compilation of statistics, insufficient interagency coordination, as well as concern about accuracy that give rise to reluctance to publish provisional data.

\section{Monetary and Financial Statistics}

The authorities have made significant progress in implementing the recommendations of STA missions, including: documentation of concepts and methodology used to compile monetary and financial statistics; revision of the reporting forms used to collect data from banks; and, completion of the development of monetary and financial statistics based on the Standardized Report Forms (SRFs), which have been published in the IFS Supplement since June 2007. Most recently, data on finance companies have been included in monetary statistics early in 2007 and data series have been retrofitted to December 2001. 
However, timely reporting of balance sheet data by some state-owned commercial banks remains problematic, and most commercial banks do not report all data needed to compile the monetary survey. Prudential data reported by state-owned banks are unreliable and not timely. The authorities should enforce the reporting obligations of banks by introducing high penalties and update the chart of accounts and accounting guidelines applied to banks and finance companies. These actions would foster consistency with the methodology in the Monetary and Financial Statistics Manual, 2000.

\section{Balance of Payments Statistics}

The 2007 multisector mission found that balance of payments statistics are generally of good quality. This is largely related to completeness of the main data source, the International Transaction Reporting System, in the context of very tight foreign exchange regulations. The mission emphasized the need to implement a survey for direct investment data. In November 2007, the authorities published the first issue of the Quarterly Statistical Bulletin, which includes balance of payments statistics. 
Algeria: TAble of Common Indicators ReQuired FOR SURVEILlance

As of December 9, 2008

\begin{tabular}{|c|c|c|c|c|c|}
\hline & $\begin{array}{c}\text { Date of } \\
\text { latest } \\
\text { observation }\end{array}$ & $\begin{array}{l}\text { Date } \\
\text { received }\end{array}$ & $\begin{array}{c}\text { Frequency } \\
\text { of } \\
\text { Data }^{7}\end{array}$ & $\begin{array}{l}\text { Frequency } \\
\quad \text { of } \\
\text { Reporting }^{7}\end{array}$ & $\begin{array}{c}\text { Frequency } \\
\text { of } \\
\text { publication }\end{array}$ \\
\hline Exchange Rates & $10 / 08$ & $11 / 17 / 08$ & $\mathrm{D}$ & M & W \\
\hline International Reserve Assets and Reserve Liabilities of the Monetary Authorities ${ }^{1}$ & $10 / 08$ & $11 / 17 / 08$ & D & M & M \\
\hline Reserve/Base Money & 09/08 & $10 / 30 / 08$ & M & M & M \\
\hline Broad Money & 09/08 & $11 / 21 / 08$ & M & M & M \\
\hline Central Bank Balance Sheet & $09 / 08$ & $10 / 30 / 08$ & M & M & A \\
\hline Consolidated Balance Sheet of the Banking System & 09/08 & $11 / 21 / 08$ & M & M & A \\
\hline Interest Rates $^{2}$ & 08/08 & $09 / 09 / 08$ & M & M & M \\
\hline Consumer Price Index & 09/08 & $11 / 17 / 08$ & M & M & M \\
\hline Revenue, Expenditure, Balance and Composition of Financing ${ }^{3}-$ General Government $^{4}$ & $\cdots$ & $\cdots$ & NA & NA & NA \\
\hline Revenue, Expenditure, Balance and Composition of Financing ${ }^{3}-$ Central Government & 09/07 & $11 / 05 / 07$ & Q & I & A \\
\hline Stocks of Central Government and Central Government-Guaranteed Debt ${ }^{5}$ & 09/07 & $11 / 05 / 07$ & Q & I & $A$ \\
\hline External Current Account Balance & $09 / 07$ & $11 / 05 / 07$ & Q & Q & A \\
\hline Exports and Imports of Goods and Services & 09/07 & $11 / 05 / 07$ & Q & Q & A \\
\hline GDP/GNP & 2007 & $11 / 24 / 08$ & A & A & A \\
\hline Gross External Debt & 09/07 & $11 / 05 / 07$ & A & A & A \\
\hline International Investment Position ${ }^{6}$ & $\ldots$ & $\ldots$ & PA & PA & PA \\
\hline
\end{tabular}

1 Includes reserve assets pledged or otherwise encumbered as well as net derivative positions.

${ }^{2}$ Both market-based and officially determined, including discount rates, money market rates, rates on treasury bills, notes and bonds.

${ }^{3}$ Foreign, domestic bank, and domestic nonbank financing.

${ }^{4}$ The general government consists of the central government (budgetary funds, extra budgetary funds, and social security funds) and state and local governments.

${ }^{5}$ Including currency and maturity composition.

${ }^{6}$ Includes external gross financial asset and liability positions vis-à-vis nonresidents. Data are partial, because of shortcomings in the compilation of FDI.

${ }^{7}$ Daily (D), Weekly (W), Monthly (M), Quarterly (Q), Annually (A); Irregular (I); and Not Available (NA), Partially available (PA). 


\section{INTERNATIONAL MONETARY FUND}

EXTERNAL

Public Information Notice

RELATIONS

DEPARTMENT

Public Information Notice (PIN) No. 09/25

FOR IMMEDIATE RELEASE

February 27, 2009

International Monetary Fund

$70019^{\text {th }}$ Street, NW

Washington, D. C. 20431 USA

\section{IMF Executive Board Concludes 2008 Article IV Consultation with Algeria}

On January, 21, 2009, the Executive Board of the International Monetary Fund (IMF) concluded the Article IV consultation with Algeria. ${ }^{1}$

\section{Background}

Algeria has enjoyed several years of strong economic performance, but continues to face important challenges. Nonhydrocarbon growth has been solid, inflation low, and the fiscal and external positions strong thanks to high hydrocarbon prices. External debt has been virtually eliminated, and the government has accumulated large savings in the oil stabilization fund (FRR). However, youth unemployment remains high, the economy is highly dependent on hydrocarbon exports, the nonhydrocarbon private sector is mainly inward oriented, and productivity and business climate are lagging compared to trading partners. The global financial crisis and declining oil prices highlight the pressing need to accelerate structural reforms to diversify the economy and ensure sustained nonhydrocarbon growth and job creation.

Economic performance remained relatively favorable in 2008 . Growth in the nonhydrocarbon sector, which represents 55 percent of total GDP, likely reached about 6 percent, as the large public investment program (PIP) continued to pull activity in services and construction. Overall growth is projected at below 3 percent, as hydrocarbon exports remained sluggish. Inflation is among the lowest in the region. Boosted by increasing oil prices until mid2008, international reserves stood at US $\$ 135$ billion in October ( $2 \frac{1}{2}$ years of imports). The

\footnotetext{
${ }^{1}$ Under Article IV of the IMF's Articles of Agreement, the IMF holds bilateral discussions with members, usually every year. A staff team visits the country, collects economic and financial information, and discusses with officials the country's economic developments and policies. On return to headquarters, the staff prepares a report, which forms the basis for discussion by the Executive Board. At the conclusion of the discussion, the Managing Director, as Chairman of the Board, summarizes the views of Executive Directors, and this summary is transmitted to the country's authorities.
} 
fiscal stance has been expansionary, but large hydrocarbon revenues translated into an overall budget surplus of 8 percent of GDP. Additional savings were accumulated in FRR, which reached 37 percent of GDP. The real effective exchange rate continued to be close to its equilibrium level.

The outlook remains encouraging despite the challenging international environment, but medium-term risks may become significant. Algeria appears insulated from direct financial contagion given the predominantly public financial sector, minimal external indebtedness, and prudent management of international reserves. Non hydrocarbon GDP growth is projected at about 6 percent in 2009, provided the government and the national hydrocarbon company, Sonatrach, draw down their savings to continue their substantial investments. Reflecting a slowdown of growth in Europe, staff projects a drop in the volume of hydrocarbon exports, bringing overall growth down to $2 \frac{1}{2}$ percent. Inflation would stay below 4 percent. The significant decline in oil prices and high imports induced by PIP and Sonatrach investments would shift the current account balance from a surplus of 20 percent of GDP in 2008 to a deficit of 3 percent in 2009, but the reserve cover would remain above 2 years of imports. The most important risk in the medium term would be continued low international oil prices, which would significantly weaken the external and fiscal positions, force a slow down of the PIP and other investments, and depress growth.

There was some progress in structural reforms, but the business climate needs to be improved. The authorities have launched various initiatives aimed at increasing the banking system's lending capacity, including budget appropriations for public bank capital and some financial restructuring of public enterprises. Loan syndication and project finance techniques have been used for large investments, as well as further corporate bond issues. Longer maturity government bonds have been listed on the Algiers stock exchange to improve price dissemination. The central bank's credit bureau is being extended to household loans. Efforts are also ongoing to deepen Algeria's integration into the regional and world economies. Nevertheless, these reforms have not yet translated into an improvement in the perception of the business climate, which continues to be ranked behind most regional competitors.

\section{Executive Board Assessment}

Executive Directors agreed with the thrust of the staff appraisal. They welcomed Algeria's strong economic performance in recent years, with solid non-hydrocarbon growth and low inflation. In particular, they commended the authorities for their sound policy stance that has enabled the accumulation of large external reserves and resources in the oil stabilization fund.

Directors observed that the immediate priority is to adopt adequate policies in response to the global crisis. They noted that Algeria's economy and financial system are relatively insulated from the global financial turmoil. However, the significant decline in oil prices, if sustained, will shift the external and fiscal positions into deficits, and, together with a prolonged recession in major trading partners, could eventually weigh on growth. Algeria also continues to face important medium-term challenges. Sustained further efforts are needed to diversify the economy and reduce dependence on the hydrocarbon sector, improve productivity and the business climate, both of which are lagging relative to trading partners, and reduce high youth unemployment. 
Directors endorsed the authorities' decision to maintain the high level of public spending in the short term to provide support to the economy and mitigate the impact of the global economic downturn. They observed that continuing the implementation of the Public Investment Program would improve infrastructure, enhance human capital, and help reduce unemployment. Directors noted that the fiscal deficits can be covered in the short term by drawing on the significant savings accumulated in recent years through prudent financial policies.

Directors welcomed the authorities' commitment to preserving competitiveness and long-term fiscal sustainability by containing current outlays, in particular the wage bill and subsidies. In that light, they supported plans to link future wage increases to productivity and economic performance. Directors stressed the need to continue ensuring the quality and efficiency of public spending, enhancing non-hydrocarbon tax collection, modernizing the budget process, and strengthening fiscal governance. Directors also welcomed the authorities' readiness to further prioritize the public investment program and their commitment to contain current expenditure and strengthen nonhydrocarbon revenues if risks of durably low oil prices materialize.

Directors commended the authorities' prudent monetary policy, which has succeeded in absorbing the banking system's structural liquidity surplus, and keeping inflation under control. They saw room for reducing interest rates, if needed, to help sustain domestic demand.

Directors considered that Algeria's exchange rate policy is consistent with external stability. They generally agreed with the staff's assessment that the exchange rate is broadly aligned with fundamentals, though noting that the assessment was sensitive to oil price volatility. Directors believed that the needed improvement in external competitiveness hinges on advancing structural reform.

Directors viewed financial sector reform as key to improving productivity, diversifying the economy, and sustaining nonhydrocarbon growth. They observed that the banking sector has coped well with the global financial crisis. Directors noted the importance of pursuing the implementation of the recommendations of the 2007 FSAP Update. In particular, it is important to continue strengthening banking supervision and regulation, reducing state involvement in the banking sector, improving the operational environment for financial intermediation, and encouraging nonbank financing.

It is expected that the next Article IV consultation with Algeria take place on the standard 12month cycle.

Public Information Notices (PINs) form part of the IMF's efforts to promote transparency of the IMF's views and analysis of economic developments and policies. With the consent of the country (or countries) concerned, PINs are issued after Executive Board discussions of Article IV consultations with member countries, of its surveillance of developments at the regional level, of post-program monitoring, and of ex post assessments of member countries with longer-term program engagements. PINs are also issued after Executive Board discussions of general policy matters, unless otherwise decided by the Executive Board in a particular case. 
Selected Economic Indicators

Prel. Proj.

$2004 \quad 2005 \quad 2006 \quad 2007 \quad 2008$

\begin{tabular}{|c|c|c|c|c|c|}
\hline \multicolumn{6}{|c|}{ (Annual percentage change, unless otherwise indicated) } \\
\hline mestic Econ & & & & & \\
\hline Real GDP & 5.2 & 5.1 & 2.0 & 3.0 & 3 \\
\hline Hydrocarbon sector & 3.3 & 5.8 & -2.5 & -0.9 & -0 \\
\hline Other sectors & 6.2 & 4.7 & 5.6 & 6.3 & \\
\hline Consumer price index (average) & 3.6 & 1.6 & 2.5 & 3.5 & 3 \\
\hline Gross national savings (in percent of GDP) & 46.2 & 51.8 & 54.9 & 57.2 & 55 \\
\hline Gross national investment (in percent of GDP) & 33.2 & 31.2 & 29.7 & 34.6 & \\
\hline
\end{tabular}

External sector

(In billions of US dollars; unless otherwise indicated)

Exports, f.o.b.

Imports, f.o.b.

Current account (in percent of GDP)

Gross official reserves

Idem, in months of next year's imports

External debt (in percent of GDP)

Debt service ratio (in percent of exports)

Terms of trade (deterioration -) (annual percent change)

Real effective exchange rate (depreciation -)

(annual percent change) 1/

$\begin{array}{rrrrr}32.2 & 46.3 & 54.7 & 60.6 & 78.2 \\ 18.0 & 19.9 & 20.7 & 26.4 & 36.3 \\ 13.1 & 20.6 & 25.2 & 22.6 & 20.2 \\ 43.1 & 56.2 & 77.8 & 110.2 & 138.9 \\ 21.0 & 26.5 & 28.0 & 27.4 & 31.0 \\ 25.6 & 16.7 & 4.8 & 3.8 & 3.0 \\ 17.6 & 12.5 & 23.8 & 2.4 & 1.7 \\ 15.5 & 33.0 & 12.4 & 1.0 & 15.2 \\ & & & & \\ 0.6 & -4.0 & 0.0 & -1.0 & -1.2\end{array}$

Central government finance

(In percent of GDP)

Total revenue

Total expenditure and net lending

Overall budget balance (deficit-)

$\begin{array}{rrrrr}36.1 & 40.9 & 43.0 & 39.6 & 45.0 \\ 29.2 & 29.0 & 29.4 & 35.1 & 36.7 \\ 6.9 & 11.9 & 13.6 & 4.5 & 8.2\end{array}$

Money and credit

(Annual percentage change, unless otherwise indicated)

Net foreign assets

Domestic credit

Credit to the government (net)

Credit to the economy

Broad money

Interest rate (central bank rediscount rate, in percent)

$\begin{array}{rrrrr}33.1 & 34.0 & 31.9 & 34.5 & 19.6 \\ -8.6 & -17.8 & -5.9 & -11.9 & -17.0 \\ -13.2 & -24.4 & -8.9 & -18.0 & -23.0 \\ 11.2 & 15.9 & 7.1 & 15.7 & 16.1 \\ 11.5 & 11.1 & 18.6 & 24.2 & 13.2 \\ 4.0 & 4.0 & 4.0 & 4.0 & 4.0\end{array}$

Sources: Algerian authorities; and Fund staff estimates and projections.

1/ For 2008, as of September. 


\section{Statement by Mohammad Mojarrad, Executive Director for Algeria and Said Maherzi, Advisor to the Executive Director \\ January 21, 2009}

Our Algerian authorities thank staff for an excellent report and constructive dialogue. They highly value Fund's advice, technical assistance, and continued support to their policies and reform efforts.

Underpinned by sound macroeconomic policies, further strides in structural reforms, sustained implementation of the important public investment program (PIP), and high oil prices over the first eight months of the year, Algeria's economic performance remained strong in 2008. Growth in the nonhydrocarbon sector reached 6 percent, unemployment declined, and the fiscal and external positions strengthened further. Inflation was contained at 4 percent on account of prudent conduct of monetary policy, continued accumulation of savings in the stabilization fund (FRR), high import content of domestic demand, and introduction of temporary price subsidies for some food products to mitigate the impact of high world commodities prices on the population.

The direct impact of the global financial crisis on the Algerian economy has been mitigated by several factors. These include limited exposure of the financial sector to international financial markets, still relatively low foreign participation in the banking sector, very low external debt, and prudent reserve management. However, the sharp decline in oil prices and prospects for a deeper recession in major trading partners are expected to heavily impact the budget and the balance of payments, with the fiscal and current accounts projected to record significant deficits as of 2009, following several years of high surpluses. While past savings and the comfortable level of reserves should support sustained implementation of the PIP, the authorities are well aware of the need for increased prudence and efficiency in the conduct of their policies to preserve macroeconomic stability. Further efforts are being made to promote private sector development to meet the challenges of diversifying the economy, anchoring sustained high growth in the nonhydrocarbon sector, and reducing the still high unemployment, especially among the youth.

Preserving long-term fiscal sustainability remains central in the authorities' strategy. Low public debt and high savings in the FRR provide sufficient room for maneuver for continued implementation of the PIP, as envisaged. Nonetheless, a high-level crisis committee has been established to monitor world economic and financial developments and provide policy recommendations as needed. In any event, the authorities stand ready to prioritize remaining projects in the PIP should financing pressures emerge. They are also committed to containing current expenditure and strengthening nonhydrocarbon revenues. Most notably, work is ongoing, with FAD's assistance, to streamline the subsidies and tax exemption system, in addition to eliminating the temporary subsidies introduced as a result of high world commodities prices. The envisaged increase in the wage bill is part of a broader civil service reform which includes a new pay and grading system to improve efficiency in public service delivery and retain skilled managers. Moving forward, wage increases will be linked to productivity and economic performance, in line with the principles set out in the National Economic and Social Pact. As recommended in the Public Expenditure Review conducted 
with World Bank assistance, increased scrutiny is being attached to the quality and efficiency of public spending, with support by the evaluation and monitoring agency (National Agency of Investment for Development) now fully operational. Medium-term expenditure frameworks (METFs) have been developed for pilot sectors as a first step towards a comprehensive METF. Work is also proceeding in further strengthening tax and customs administration, in accordance with FAD's recommendations, while progress is being made to modernize budget management and enhance governance, including with the finalization of the draft organic law and implementation of the anti-corruption law.

Monetary policy in 2008 continued to be geared successfully to containing inflation, including by mopping up excess liquidity. Inflationary pressures from high world commodities prices have now eased and excess liquidity in the banking system has declined as a result of lower oil prices, thereby providing space for monetary easing should the need to support economic activity arise. The authorities share staff's conclusion that the real effective exchange rate is broadly in line with its equilibrium level and welcome their assessment that policies are consistent with external stability. They remain committed to their flexible exchange rate policy to ensure that the real effective exchange rate remains close to its equilibrium level. They believe that improving the competitiveness of the economy hinges on further advancing structural reforms and improving the business environment and are committed to sustaining their efforts in this regard.

The banking system remains sound and profitable. Credit to the economy continued to grow at a moderate rate despite ample liquidity, reflecting strengthened credit risk assessment. To further improve the resilience of the system and increase its lending capacity, the required minimum capital for banks has been significantly increased in December 2008. To meet this requirement, public banks will use provisions on loans to public enterprises that will be freed under the ongoing public restructuring program. Continued efforts are being made to further strengthen banking supervision, including with Fund technical assistance. The authorities remain committed to reducing state involvement in the banking sector. They intend to reactivate the privatization process of Crédit Populaire d'Algérie (CPA), one of the public banks, as soon as global financial conditions stabilize. 